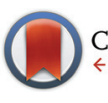

CrossMark \& click for updates

Cite this: Dalton Trans., 2015, 44 12326

Received 15th January 2015,

Accepted 24th February 2015

DOI: $10.1039 / c 5 d t 00192 \mathrm{~g}$

www.rsc.org/dalton

\title{
Comparing a series of 8-quinolinolato complexes of aluminium, titanium and zinc as initiators for the ring-opening polymerization of rac-lactide $\uparrow$
}

\author{
Clare Bakewell, ${ }^{a}$ Giovanna Fateh-Iravani, ${ }^{a}$ Daniel W. Beh, ${ }^{a}$ Dominic Myers, ${ }^{a}$ \\ Sittichoke Tabthong, ${ }^{\mathrm{b}}$ Pimpa Hormnirun, ${ }^{\mathrm{b}}$ Andrew J. P. White, ${ }^{\mathrm{a}}$ Nicholas Long ${ }^{\star a}$ and \\ Charlotte K. Williams ${ }^{* a}$
}

\begin{abstract}
The preparation and characterization of a series of 8-hydroxyquinoline ligands and their complexes with Ti(Iv), Al(III) and $\mathrm{Zn}(I)$ centres is presented. The complexes are characterized using NMR spectroscopy, elemental analysis and, in some cases, by single crystal X-ray diffraction experiments. The complexes are compared as initiators for the ring-opening polymerization of racemic-lactide; all the complexes show moderate/good rates and high levels of polymerization control. In the case of the titanium or aluminium complexes, moderate iso-selectivity is observed $\left(P_{\mathrm{i}}=0.75\right)$, whereas in the case of the zinc complexes, moderate hetero-selectivity is observed $\left(P_{\mathrm{s}}=0.70\right)$.
\end{abstract}

\section{Introduction}

Lewis acidic metal alkoxide/amide complexes have become popular choices as the initiators in the ring-opening polymerization of lactones. ${ }^{1}$ This is relevant because ROP can be used to prepare bio-derived and/or bio-compatible polyesters, such as polylactide which are proposed as sustainable alternatives to common petrochemicals. ${ }^{2}$ Metal catalysed, or more precisely initiated, polymerizations are proposed to occur by a coordination-insertion mechanism whereby the Lewis acidic metal centre coordinates the lactide, activating it to attack by a metal bound alkoxide group. This attack leads to ring-opening and generation of a new metal alkoxide species. The selection of the initiator is important as it affects features such as the polymerization rate, the degree of polymerization control (endgroups/molecular weight, dispersity, facility to form block copolymers) and the stereocontrol. Initiators which are able to efficiently produce PLA, with stereocontrol are of interest as the different tacticities of PLA result in different performances, in particular in different thermal and mechanical properties. ${ }^{1 a-d}$ Well-defined, i.e. ligated, metal complexes are frequently targeted as catalysts; they are particularly attractive as the ligand-metal interactions moderate and control the

\footnotetext{
${ }^{a}$ Department of Chemistry, Imperial College London, London SW7 2AZ, UK. E-mail: c.k.williams@imperial.ac.uk,n.long@imperial.ac.uk

${ }^{b}$ Department of Chemistry, Faculty of Science, Kasetsart University, Bangkok 10900, Thailand

$\dagger$ Electronic supplementary information (ESI) available. CCDC 1043547-1043549. For ESI and crystallographic data in CIF or other electronic format see DOI: 10.1039/c5dt00192g
}

catalysis. The application of earth-abundant metal centres is especially desirable as a means to reduce the cost and improve sustainability of the initiator selection. There is already a strong track record for use of some of the most earth-abundant metal centres including successful initiators of $\mathrm{Al}(\mathrm{III}),{ }^{3} \mathrm{Fe}(\mathrm{III}),{ }^{4}$ $\mathrm{Ca}(\mathrm{II}),{ }^{5} \mathrm{Mg}(\mathrm{II}),{ }^{5 b, d, 6} \mathrm{Na}(\mathrm{I}),{ }^{7} \mathrm{~K}(\mathrm{II})^{7 a, 8}$ and $\mathrm{Ti}(\mathrm{IV}) .{ }^{9}$ Despite these successes there is still a strong drive for new initiators particularly those able to exert high degrees of polymerization control, especially stereocontrol.

\section{Results and discussion}

Our approach was to prepare complexes of earth abundant elements using a series of easily synthesised and moderated ancillary ligands. The use of 8-hydroxyquinoline ligands is attractive as they are either commercially available or easily synthesised and, from the point of view of catalysis, offer a large range of different sites for substitution, most notably at positions $R_{1-3}$, which enable modifications of the steric and electronic features of the complexes. ${ }^{10}$ Some of us have previously reported Group 13 complexes of several 8-hydroxyquinoline ligands; these complexes are slow but iso-selective initiators in the polymerization of rac-lactide. ${ }^{10 b}$ It was discovered that modifications to the $R_{1}$ and $R_{3}$ substituents led to increased iso-selectivity and polymerization activity, respectively. ${ }^{10 b}$ Further, the (8-quinolinolato)gallium analogues were significantly faster initiators highlighting the importance of the metal centre in moderating catalysis. ${ }^{10 a, b}$ It was, therefore, of interest to explore a wider range of 8-hydroxyquinoline 
complexes, using $\mathrm{Al}(\mathrm{III}), \mathrm{Ti}(\mathrm{Iv})$ and $\mathrm{Zn}$ (II), to explore the effects on polymerization catalysis.

\section{Pro-ligand syntheses}

A series of 8-hydroxyquinoline pro-ligands were selected for the study; their structures are illustrated in Fig. 1. Pro-ligands A-D are either commercially available or were prepared by previously described literature procedures and all have methyl substituents at position $\mathrm{R}_{3}$ and a range of different halides/H at positions $\mathrm{R}_{1}$ and $\mathrm{R}_{2} \cdot{ }^{10 b}$ Pro-ligand $\mathbf{E}$ was also prepared by a modified literature route (see ESI $\dagger$ ) and differs from ligand $\mathbf{D}$ by having a larger phenyl substituent at position $\mathrm{R}_{3}{ }^{11}$ Compounds $\mathbf{F}$ and $\mathbf{G}$ have phenyl and ethynyl ferrocene substituents at position $\mathrm{R}_{1}$, with the other substituents being the same as ligand $\mathbf{A}$. They were targeted to investigate the influence of aromatic substituents at the position ortho- to the phenolate moiety. Compounds $\mathbf{F}$ and $\mathbf{G}$ were prepared from the mixed halide pro-ligand $\mathbf{B}$, via sequences of protection of the phenol group; followed by cross-coupling reactions with the iodo-

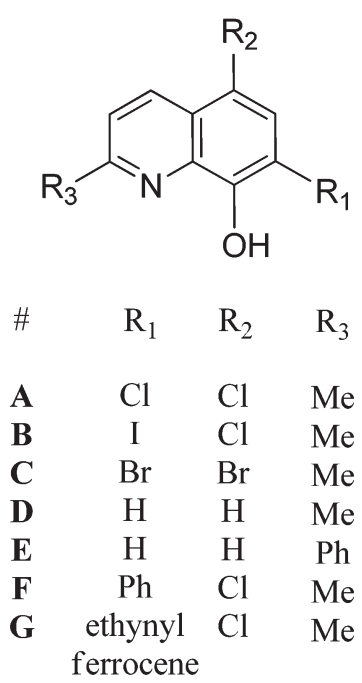

Fig. 1 The structures of a series of 8-hydroxyquinoline compounds A-G. substituent $\left(\mathrm{R}_{1}\right)$ using Suzuki (for $\mathbf{F}$ ) or Sonagashira (for $\mathbf{G}$ ) methods; followed by deprotection of the phenol which enabled isolations in good overall yields (57\% for $\mathbf{F}$ and $68 \%$ for $\mathbf{G})$. The new pro-ligands $\mathbf{E}-\mathbf{G}$ were fully characterised by NMR spectroscopy, mass spectrometry and the stoichiometry was confirmed by elemental analysis. Further details of the ligand syntheses are available in the ESI (Schemes S1 and 2†).

\section{Complex syntheses}

Aluminium complexes. We have previously reported bis(8quinolinolato) aluminium ethyl complexes, [ $\mathrm{L}_{2} \mathrm{AlEt}$ ] where $\mathrm{L}=$ ligands A-D. ${ }^{10 b}$ The catalytic performance data are included for reference here and the complexes are labelled $\mathbf{A l}-\mathbf{A} / \mathbf{B} / \mathbf{C} / \mathbf{D}$, respectively. New analogous bis(8-quinolinolato) aluminium ethyl complexes, Al-E, Al-F and Al-G, were synthesised by the reaction of two equivalents of the relevant 8-hydroxyquinoline pro-ligands, (E, F or $\mathbf{G}$ ), with triethyl aluminium, in toluene at 298 K (Fig. 2). Compounds Al-E and Al-F were isolated as crystalline yellow (Al-E or Al-F) or orange (Al-G) solids (isolated yields: 71\% Al-E; 34\% Al-F; 63\% Al-G). The new complexes were characterized using ${ }^{1} \mathrm{H}$ NMR spectroscopy, where signals assigned to protons on the ligands and those assigned to the aluminium coordinated ethyl group were observed. The ligand signals were typically observed at lower chemical shift compared to the pro-ligands, consistent with coordination to a Lewis acidic metal centre (Al). A triplet was observed at 0.21, 1.05 and $0.67 \mathrm{ppm}$, for $\mathbf{A l}-\mathbf{E} / \mathbf{F} / \mathbf{G}$, respectively, assigned to the methyl protons of the aluminium ethyl group. Two quartets were typically observed at $0.25-0.75 \mathrm{ppm}$ due to the diastereotopic methylene protons on the same aluminium ethyl group. It is notable that the diastereotopic methylene protons of compound Al-E were observed at a considerably lower shift, -1.08 ppm, with the two quartets only being observable using a higher resolution $500 \mathrm{MHz}$ NMR instrument. The observed signal multiplicity for the aluminium ethyl groups is in line with the characterization data for the previously reported complexes. ${ }^{10 b}$ The purity of the new complexes Al (E-G) was confirmed by elemental analyses.

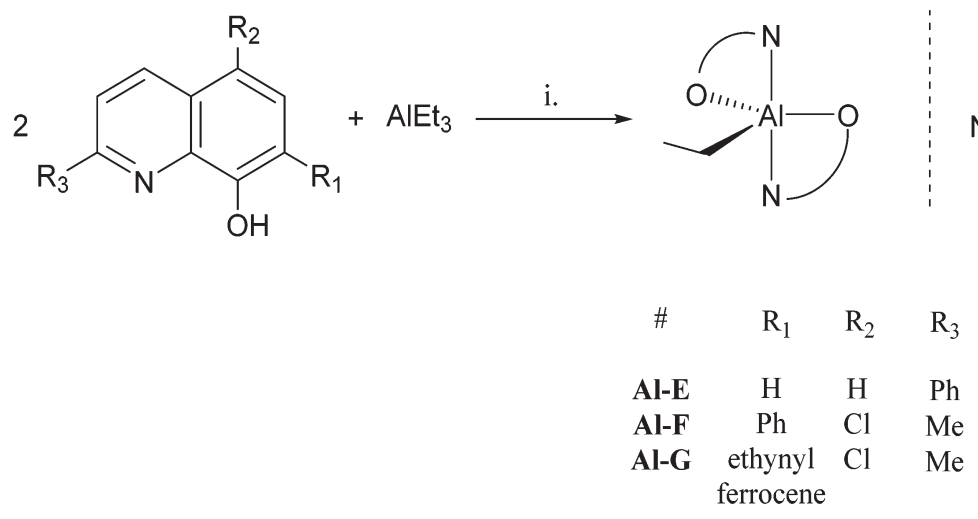

Fig. 2 General synthesis of initiators Al-E, F and G, numbering scheme included. Reagents and conditions: i. AlEt 3, toluene, $298 \mathrm{~K}, 12 \mathrm{~h}, \mathrm{Al}-\mathrm{E}$ (71\%), Al-F (34\%), Al-G (63\%). 
<smiles>[R]c1ccc2c([R])cc([R])c(O)c2n1</smiles><smiles>[R3]c1ccc2c([R2])cc([R7])c([O-])c2n1</smiles>

Titanium(Iv) complexes. A series of three new bis(8-quinolinolato) bis(iso-propoxide) titanium(rv) complexes, $\left[\mathrm{L}_{2} \mathrm{Ti}(\mathrm{OiPr})_{2}\right]$ were targeted, where $\mathrm{L}$ was selected based on a precedent for formation of high activity/selectivity aluminium catalysts as well as applying new pro-ligand $\mathbf{G}$ (aromatic $\mathrm{R}_{1}$ substituent) (Fig. 3). Thus, compounds Ti-B, Ti-D and Ti-G were synthesised by reaction of one equivalent of titanium(Iv) tetrakis(iso-propoxide) with two equivalents of ligands $\mathbf{B}, \mathbf{D}$ and $\mathbf{G}$, respectively, in toluene solution, at $298 \mathrm{~K}$. The new complexes were isolated as yellow (Ti-B and $\mathbf{D}$ ) or orange (Ti-G) solids in moderate to good yields $(43-70 \%)$.

The new compounds were characterised by NMR spectroscopy and the purity was confirmed by elemental analysis. The characteristic peaks of the iso-propoxy alkoxide groups resonate as a septet (4.8-5.2 ppm) and a doublet of doublets (1.2-1.4 ppm), and integrate at a $1: 1$ ratio with the quinolinate peaks confirming the proposed complex stoichiometry. Although X-ray crystal structures of the new titanium(Iv) complexes were not obtained, the complexes are proposed to adopt distorted octahedral geometries with the $\mathrm{N}$ atoms, of the quinolinate ligands, being in a cis-disposition to one another and the O-atoms being in trans-positions (see Fig. 3). Such a geometry is different to that observed for the pentacoordinate $\mathrm{Al}(\mathrm{III})$ complexes, but is in line with other X-ray crystal structures reported for closely related bis(8-quinolinolato) bis(isopropoxide) complexes of titanium(rv). ${ }^{12}$

Zinc complexes. Although zinc is not as prevalent an element as $\mathrm{Al}$ or $\mathrm{Ti}$, it is of interest to investigate its coordination chemistry with the 8 -hydroxyquinoline ligands. This is because of the strong track record of zinc alkoxide initiators showing high rates and stereoselectivity. A series of (8-quinolinolato)zinc ethyl complexes, [LZnEt] where $\mathrm{L}$ is ligand $\mathbf{A}-\mathbf{E}, \mathbf{G}$, were prepared (Fig. 4). The 8-hydroxyquinoline pro-ligands (A-E and G) were reacted with an equimolar quantity of diethyl zinc, in toluene, at $298 \mathrm{~K}$. During the course of the reaction a precipitate formed which, after stirring for 12 hours, was isolated by filtration to yield the zinc complexes as yellow (Zn-AE) or orange (Zn-F) solids in good yields (55-78\%). The new compounds were characterised by NMR spectroscopy and the purity was confirmed by elemental analysis. The ${ }^{1} \mathrm{H}$ NMR

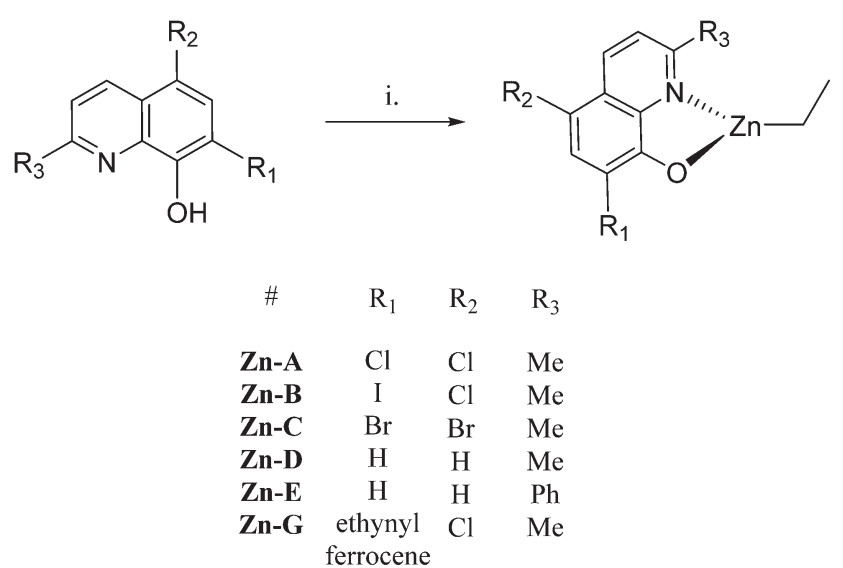

Fig. 4 General synthesis of initiators Zn-A, B, C, E and G, numbering scheme included. Reagents and conditions: i. ZnEt ${ }_{2}$, toluene, $298 \mathrm{~K}$, 12 h, Zn-A (78\%), Zn-B (70\%), Zn-C (56\%), Zn-D (67\%). Zn-E (70\%), Zn-G $(60 \%)$.

spectra showed the characteristic shift to lower chemical shifts in the ligand signals compared to those of the pro-ligands. The zinc ethyl groups showed a quartet, at $\sim 0.4 \mathrm{ppm}$, due to the methylene protons, and a triplet, at $1.2-1.3 \mathrm{ppm}$, assigned to the methyl protons.

Single crystal X-ray diffraction experiments revealed that compound Zn-A exists as a dimer in the solid state, vide infra. On the basis of this finding, it is tentatively assumed that other complexes with sterically hindered substitutents at sites $\mathrm{R}_{1}$ and $\mathrm{R}_{2}$ are also dimeric in the solid state, i.e. complexes $\mathbf{Z n}$ (A-C) and Zn-G. Consistent with this proposal is the finding that these complexes (Zn-(A-C), Zn-G) all showed well-defined ${ }^{1} \mathrm{H}$ NMR spectra, when dissolved in THF- $d_{8}$. In contrast, the ${ }^{1} \mathrm{H}$ NMR spectra of compounds Zn-D and Zn-E (where $\mathrm{R}_{1}=$ $\mathrm{R}_{2}=\mathrm{H}$ ), in THF- $d_{8}$ at $298 \mathrm{~K}$, are broad and undefined, thus indicative of higher degrees of aggregation. The use of a stronger donor solvent, pyridine- $d_{5}$, resulted in well-defined ${ }^{1} \mathrm{H}$ NMR spectra being obtained, consistent with the pyridine coordinating to the zinc centre and favouring the formation of discrete mononuclear complexes. Indeed, there is already a 
good literature precedent for the formation of high order clusters/aggregates for unsubstituted (8-quinolinolato)zinc(tertbutyl) complexes. ${ }^{13}$ There is also a track record for pyridine coordinating to zinc complexes and disrupting aggregate structures. ${ }^{14}$ To further confirm the structures of Zn-D, a single crystal X-ray diffraction experiment (vide infra) showed the complex exhibited a trimeric structure in the solid state.

\section{X-ray crystallography}

Single crystals, suitable for X-ray diffraction experiments, were isolated for compounds Zn-A, Zn-D and Al-E from THF-hexane and toluene solutions, respectively. The crystallizations occurred at $-18^{\circ} \mathrm{C}$ for $\mathbf{Z n}-\mathbf{D}$ and Al-E and at $25^{\circ} \mathrm{C}$ for $\mathbf{Z n}-\mathbf{A}$. Illustrations of the structures are shown in Fig. 5-8 and Table 1 presents selected bond lengths and angles (for full data see the ESI $\dagger$ ).

The structure of the aluminium complex Al-E shows a distorted trigonal bipyramidal coordination geometry $(\tau=0.62)$ for the aluminium centre, with $\mathrm{N} 1$ and N21 occupying the axial sites (Fig. 5). Both of the $\mathrm{C}_{2} \mathrm{NOZn}$ chelate rings have envelope conformations; for the N1/O9 chelate ring the metal lies $c a .0 .12 \AA$ out of the $\mathrm{C}_{2} \mathrm{NO}$ plane (the atoms of which are coplanar to within ca. $0.01 \AA$ ), whilst for the N21/O29 case the aluminium lies ca. $0.18 \AA$ out of the plane of the other four atoms (which are coplanar to better than $0.01 \AA$ ).

The structures of the two zinc complexes confirm the formation of aggregates in the solid state, presumably driven in part by the high stability of four coordinate, tetrahedral zinc

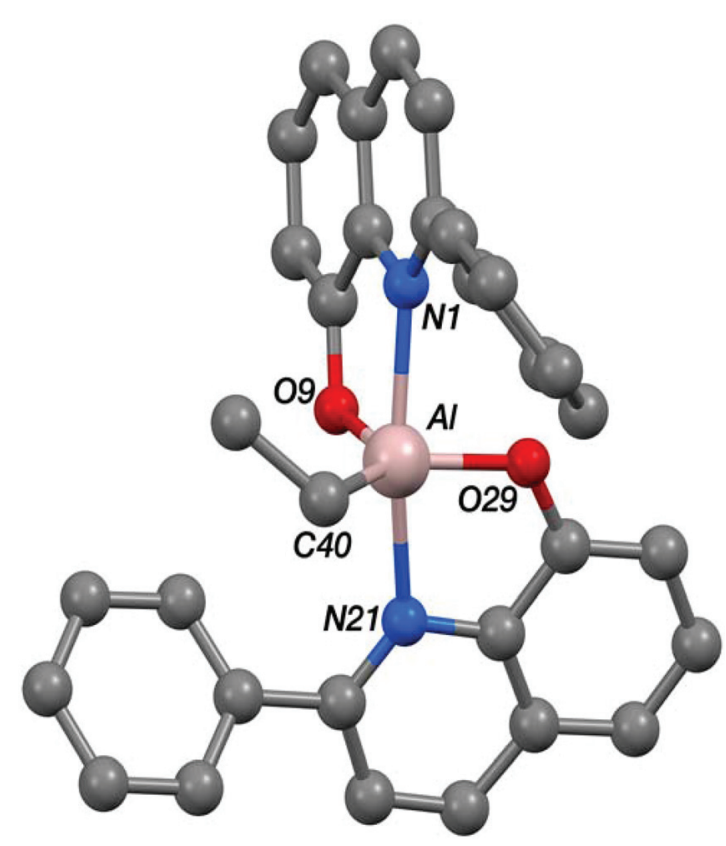

Fig. 5 The crystal structure of Al-E. Selected bond lengths (Å) and angles $\left({ }^{\circ}\right)$; Al-N1 2.1892(10), Al-O9 1.7989(9), Al-N21 2.1527(10), AlO29 1.8007(10), Al-C40 1.9746(13), N1-Al-O9 82.28(4), N1-Al-N21 165.14(4), N1-Al-O29 89.27(4), N1-Al-C40 94.77(5), O9-Al-N21 88.62(4), O9-Al-O29 109.02(5), O9-Al-C40 122.89(5), N21-Al-O29 82.59(4), N21-Al-C40 100.04(5), O29-Al-C40 128.02(5).

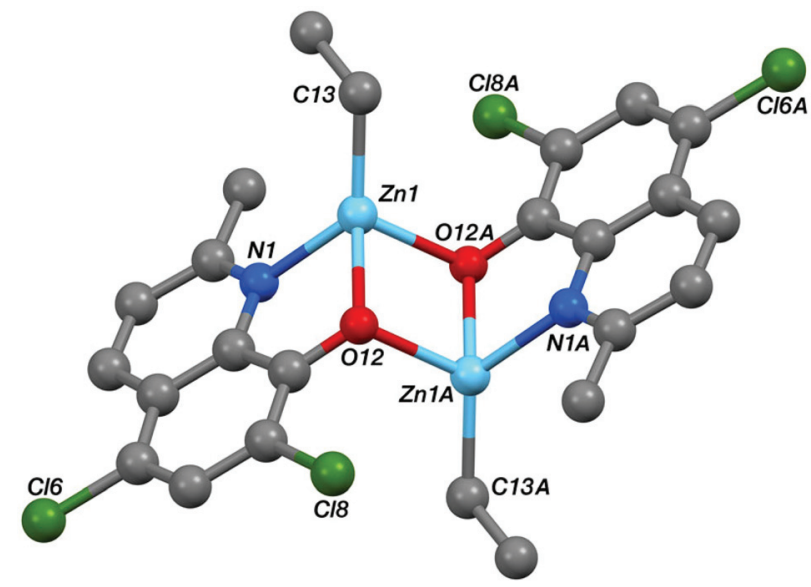

Fig. 6 The crystal structure of the $C_{i}$-symmetric complex $\mathrm{Zn}-\mathrm{A}$. Selected bond lengths ( $(\AA)$ and angles $\left({ }^{\circ}\right)$; Zn1-N1 2.0866(17), Zn1-O12 2.0776(14), Zn1-C13 1.984(2), Zn1-O12A 2.0761(15), Zn1‥Zn1A 3.09986, N1-Zn1-O12 80.54(6), N1-Zn1-C13 128.80(8), N1-Zn1-O12A 105.43(6), O12-Zn1-C13 129.36(8), O12-Zn1-O12A 83.46(6), C13Zn1-O12A 117.05(8).

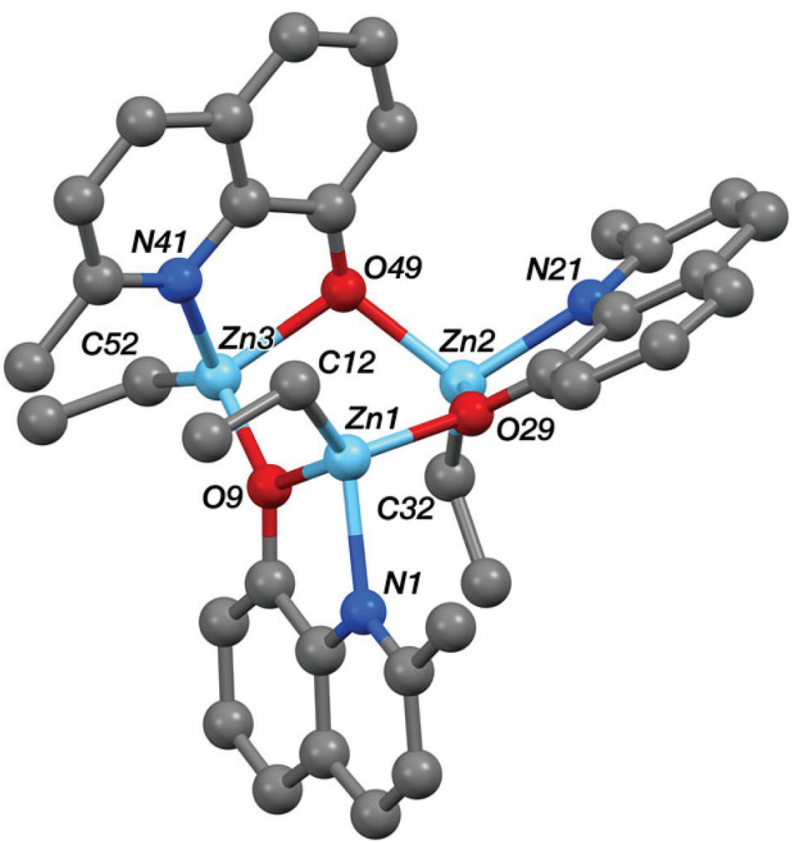

Fig. 7 The crystal structure of $Z n-D$, see Table 1 for selected bond lengths and angles.

centres. The crystal structure of $\mathbf{Z n - A}$ shows the complex to be a $C_{\mathrm{i}}$-symmetric dimer with bridging phenoxide oxygen atoms (Fig. 6). The geometry at the zinc centre is noticeably distorted with the angles involving the ethyl ligand all being significantly increased from ideal, ranging between 117.05(8) and $129.36(8)^{\circ}$. The five-membered $\mathrm{C}_{2} \mathrm{NOZn}$ chelate ring has an envelope conformation, the zinc atom lying ca. $0.41 \AA$ out of the plane of the other four atoms (which are coplanar to within ca. $0.01 \AA$ ). In contrast, the crystal structure of Zn-D shows a trimeric, cyclic structure based on three EtZn-D units 


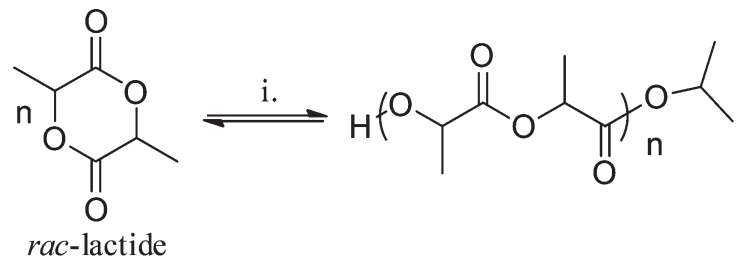

Fig. 8 Illustrates the ring-opening polymerization of lactide to polylactide. Reagents and Conditions: Polymerization conditions: Al-(A-G): Toluene, $348 \mathrm{~K}, 1: 1: 100$ [I] : [iPrOH] : [LA], 1 M [LA]. Ti-(B/D/G): Toluene, $348 \mathrm{~K}, 1: 100$ [I] : [LA], $1 \mathrm{M}$ [LA]. Zn-(A-G): THF/CH ${ }_{2} \mathrm{Cl}_{2}, 298 \mathrm{~K}, 1: 1: 100$ [I] : [iPrOH] : [LA], $1 \mathrm{M}$ [LA].

(Fig. 7, Table 1). The $\mathrm{Zn}_{3} \mathrm{O}_{3}$ ring has a "two-up one-down" arrangement for the quinolinolate ligands; this ring has a twist-boat conformation with $\mathrm{Zn} 3$ and O49 lying $c a$. 1.42 and $1.85 \AA$, respectively, out of the [Zn1, Zn2, O9, O29] plane (which is coplanar to $c a$. $0.11 \AA$ ). All three zinc centres have distorted tetrahedral coordination geometries with angles in the ranges $81.20(7)-125.24(10)^{\circ}, 80.85(7)-128.93(9)^{\circ}$ and $80.57(7)-130.87(11)^{\circ}$ at $\mathrm{Zn} 1, \mathrm{Zn} 2$ and $\mathrm{Zn} 3$ respectively; in each case the smallest angle is the bite of the N,O chelate ligand. Two of the three five-membered $\mathrm{C}_{2} \mathrm{NOZn}$ chelate rings are approximately flat (the $\mathrm{Zn} 1$ and $\mathrm{Zn} 2$ based rings are coplanar to within $c a$. 0.02 and $0.03 \AA$ respectively), whilst the third has an envelope conformation with Zn3 lying $c a$. $0.11 \AA$ out of the plane of the other four atoms which are coplanar to within ca. $0.01 \AA$.

It is notable that ligand $\mathbf{G}$ contains a redox-active ferrocene substituent and a number of catalysts containing such substituents have been shown to be capable of control/moderation of the polymerization properties by control of ferrocene redox chemistry. ${ }^{9 g, h, 15}$ Thus, it was relevant to investigate the redox chemistry of compounds Al-G, Ti-G and Zn-G. Cyclic voltammetry showed all three compounds to have reversible redox behaviour, however chemical oxidation proved problematic. Ethyl compounds Al-G and Zn-G showed evidence of alkyl abstraction using a range of different chemical oxidants including $\mathrm{Ag}^{+} \mathrm{OTf}^{-}, \mathrm{Ag}^{+} \mathrm{BF}_{4}^{-}, \mathrm{NO}^{+} \mathrm{BF}_{4}^{-}, \mathrm{Fc}^{+} \mathrm{PF}_{6}^{-}$and $\mathrm{Fc}^{+} \mathrm{BAr}^{\mathrm{F}-}$, as signalled by the absence of the characteristic ethyl group signals in the ${ }^{1} \mathrm{H}$ NMR spectra. Attempts to chemically oxidise compound Ti-G, a titanium bis(iso-propoxide) species, also failed to result in a paramagnetic $\mathrm{Fe}(\mathrm{III})$ species and showed poor stability of any chemically oxidised product formed. As such, compounds Al-G, Ti-G and $\mathbf{Z n - G}$ cannot be redox controlled, rather they are included in this study as initiators containing aromatic/sterically hindered substituents at position $\mathrm{R}_{1}$.

\section{Ring-opening polymerization of rac-lactide}

All the new compounds ( $\mathbf{A l}, \mathbf{Z n}$ and $\mathbf{T i}$ ) were tested as initiators for the ROP of rac-LA and for ease of comparison, the data for Al-(A-D) is also included (Fig. 8, Table 2).

The polymerizations were conducted under a standard set of conditions; in toluene at $348 \mathrm{~K}$ for the aluminium and titanium complexes (note: an equivalent of iso-propyl alcohol was added to polymerizations using aluminium ethyl initiators) or in THF-methylene dichloride, at $298 \mathrm{~K}$, with one equivalent of iso-propyl alcohol for the zinc initiators. All experiments were conducted at a standard concentration of rac-lactide (1 M) and using $10 \mathrm{mM}$ concentration of initiator (i.e. 1:100 loading of initiator : lactide). In the case of the ethyl based initiators, i.e. all the $\mathrm{Al}$ and $\mathrm{Zn}$ complexes, an equivalent of iso-propyl alcohol was added. This alcohol reacts with the metal ethyl bond, in situ, forming an active metal iso-propoxide initiator. The polymerizations are all air and moisture sensitive and so were carried out in a nitrogen filled glovebox or on an argon Schlenk line. The polymerizations were monitored by taking aliquots at regular time intervals. The crude samples (aliquots) were then analysed using ${ }^{1} \mathrm{H}$ NMR spectroscopy to determine the percentage monomer conversion. Size exclusion chromatography was used to determine the number-averaged molecular weight $\left(M_{\mathrm{n}}\right)$ and dispersity (PDI) for all samples. The tacticity of the resulting PLA was assessed by integration of the methyne region of the homonuclear decoupled NMR spectrum. The normalized tetrad integrals were compared with the expected probabilities determined by Bernoullian statistics. ${ }^{16}$

All the complexes were active initiators in the polymerization of rac-LA, the polymerization results are summarised in Tables 2 and 3.

The $\mathrm{Al}$ and Ti initiators showed similar performances, exhibiting slow rates compared to the very best catalysts for lactide polymerization but at values as expected for these metal centres. The polymerization kinetics were monitored for $\mathbf{A l}$ and Ti initiators, showing first order dependencies on lactide concentration in all cases; the pseudo first order rate constants, $k_{\mathrm{obs}}$, were obtained as the gradient of the linear fits to plots of $\ln \left([\mathrm{LA}]_{0} /[\mathrm{LA}]_{t}\right)$ versus time (Fig. 9, 10 and ref. $10 \mathrm{~b}$ for the data for $\mathbf{A l}(\mathbf{A}-\mathbf{D}))$. Of the Al compounds, Al-E $\left(\mathrm{R}_{3}=\mathbf{P h}\right)$

Table 1 Selected bond lengths ( $(\AA)$ and angles $\left(^{\circ}\right)$ for $\mathrm{Zn}-\mathrm{D}$

\begin{tabular}{lllll}
\hline Zn1-N1 & $2.083(2)$ & Zn2-N21 & $2.083(2)$ & Zn3-N41 \\
Zn1-O9 & $2.0514(17)$ & Zn2-O29 & $2.0487(16)$ & Zn3-O49 \\
Zn1-C12 & $1.975(3)$ & Zn2-C32 & $1.977(3)$ & Zn3-C52 \\
Zn1-O29 & $2.0215(16)$ & Zn2-O49 & $2.0427(17)$ & Zn3-O9 \\
& & & & $2.0537(16)$ \\
N1-Zn1-O9 & $81.20(7)$ & N21-Zn2-O29 & $80.85(7)$ & N41-Zn3-O49 \\
N1-Zn1-C12 & $123.03(10)$ & N21-Zn2-C32 & $125.24(10)$ & N41-Zn3-C52 \\
N1-Zn1-O29 & $101.28(7)$ & N21-Zn2-O49 & $108.13(7)$ & N41-Zn3-O9 \\
O9-Zn1-C12 & $125.24(10)$ & O29-Zn2-C32 & $128.93(9)$ & O49-Zn3-C52 \\
O9-Zn1-O29 & $94.00(7)$ & O29-Zn2-O49 & $95.89(7)$ & O49-Zn3-O9 \\
C12-Zn1-O29 & $122.22(10)$ & C32-Zn2-O49 & $111.70(9)$ & C52-Zn3-O9
\end{tabular}


Table 2 Polymerization data obtained using initiators Al-(A-G) and Ti-B, D, G

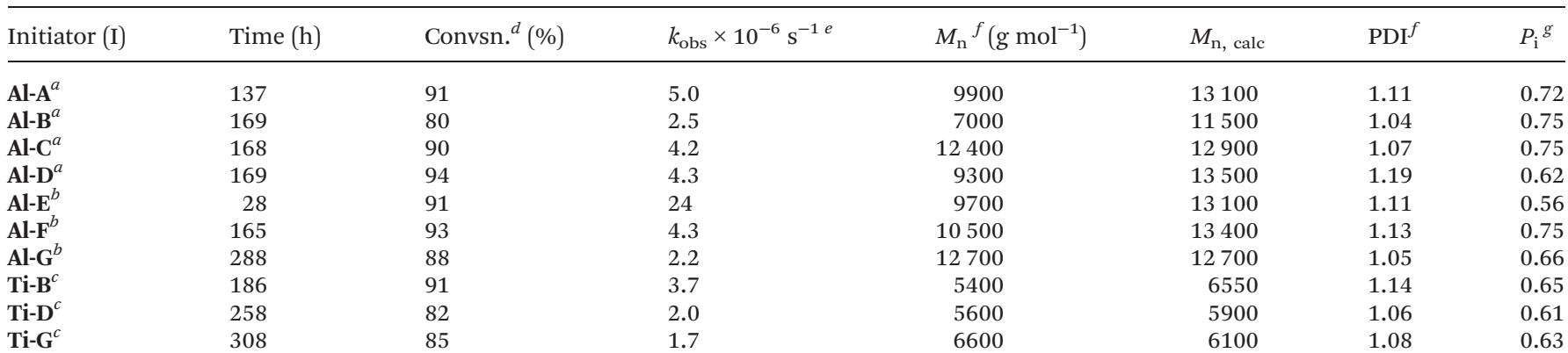

${ }^{a}$ The results are reproduced from ref. $10 b$ to enable comparisons between the initiators. ${ }^{b}$ Polymerization conditions: Toluene, $348 \mathrm{~K}, 1: 1: 100$ [I]: [iPrOH]: [LA], $1 \mathrm{M}$ [LA]. ${ }^{c}$ Toluene, $348 \mathrm{~K}, 1: 100$ [I]: [LA], $1 \mathrm{M}$ [LA]. ${ }^{d}$ Determined by integration of the methine region of the ${ }^{1} \mathrm{H}$ NMR spectrum (LA 4.98-5.04 ppm; PLA 5.08-5.22 ppm). ${ }^{e}$ Determined from the gradients of the plots of $\ln \left\{[\text { LA }]_{0} /[\mathrm{LA}]_{t}\right\}$ versus time. ${ }^{f}$ Determined by GPC-SEC in THF, using a correction factor of $0.58 .^{3 a g}$ Determined by analysis of all the tetrad signals in the methine region of the homonuclear decoupled ${ }^{1} \mathrm{H}$ NMR spectrum.

Table 3 Polymerization data obtained using initiators $\mathrm{Zn}-\mathrm{A}-\mathrm{E}$ and G

\begin{tabular}{|c|c|c|c|c|c|c|c|c|c|c|}
\hline $\mathrm{I}^{a}$ & Solv. & Time (min) & Conv. $^{b}(\%)$ & $k_{\mathrm{obs}} \times 10^{-4} \mathrm{~s}^{-1 c}$ & $M_{\mathrm{n}, \text { theo. }}$ & $M_{\mathrm{n}, \mathrm{NMR}}{ }^{d}\left(\mathrm{~g} \mathrm{~mol}^{-1}\right)$ & $M_{\mathrm{n}, \mathrm{LS}}{ }^{e}\left(\mathrm{~g} \mathrm{~mol}^{-1}\right)$ & $M_{\mathrm{n}, \mathrm{SEC}}{ }^{f}\left(\mathrm{~g} \mathrm{~mol}^{-1}\right)$ & $\mathrm{PDI}^{e, f}$ & $P_{\mathrm{s}}{ }^{g}$ \\
\hline Zn-A & DCM & 260 & 90 & 1.7 & 13000 & 8500 & 8900 & 5600 & 1.03 & 0.60 \\
\hline Zn-B & DCM & 200 & 92 & 2.4 & 13250 & 8750 & 9000 & - & 1.03 & 0.60 \\
\hline Zn-C & THF & 370 & 93 & 1.6 & 13400 & 8000 & 9400 & 6200 & 1.03 & 0.66 \\
\hline Zn-C & DCM & 290 & 95 & 1.8 & 13700 & 9900 & 9100 & 6400 & 1.08 & 0.60 \\
\hline Zn-D & THF & 560 & 85 & 0.8 & 12300 & - & 8000 & 7000 & 1.07 & 0.67 \\
\hline
\end{tabular}

${ }^{a}$ Polymerization conditions: $298 \mathrm{~K}, 1: 1: 100[\mathrm{I}]:[\mathrm{iPrOH}]:[\mathrm{LA}], 1 \mathrm{M}[\mathrm{LA}] .{ }^{b}$ Determined by integration of the methine region of the ${ }^{1} \mathrm{H}$ NMR spectrum (LA 4.98-5.04 ppm; PLA 5.08-5.22 ppm). ${ }^{c}$ Determined from the gradients of the plots of $\ln \left\{[\mathrm{LA}]_{0} /[\mathrm{LA}]_{t}\right\}$ versus time. ${ }^{d}$ Determined by integration of the hydroxyl chain-end versus the polymer methine protons. ${ }^{e}$ Determined by GPC in THF, using multiangle laser light scattering (GPC-MALLS). ${ }^{f}$ Determined by GPC in THF versus polystyrene standard and a correction factor on $0.58 .{ }^{g}$ Determined by analysis of all the tetrad signals in the methine region of the homonuclear decoupled ${ }^{1} \mathrm{H}$ NMR spectrum.

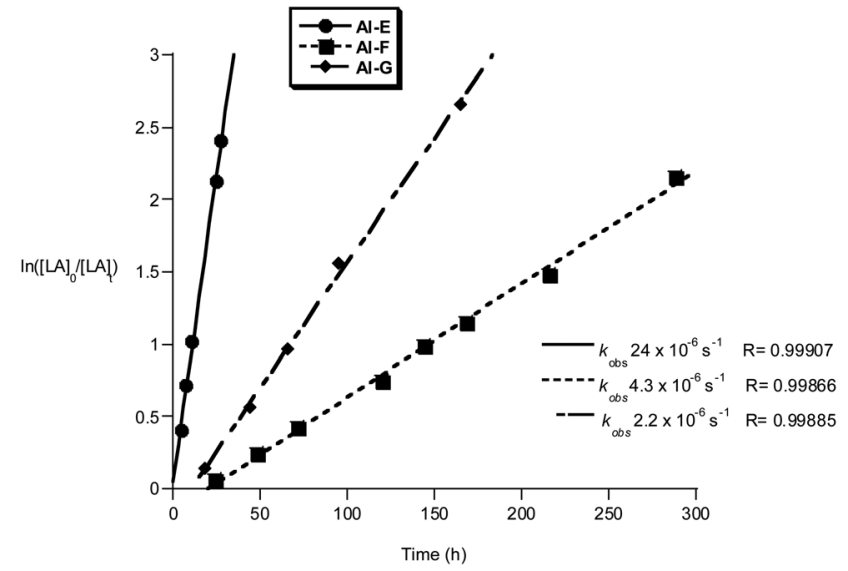

Fig. 9 Plot of $\ln \left([L A]_{0} /[L A]_{t}\right)$ vs. time of initiator Al-E, F and G. Conditions: $[\mathrm{LA}]_{0}=1 \mathrm{M}, 1: 1: 100[\mathrm{I}]:[\mathrm{iPrOH}]:[\mathrm{LA}]$, toluene, $348 \mathrm{~K}$.

stands out as having a significantly faster rate $\left(k_{\text {obs }}=24 \times 10^{-6}\right.$ $\left.\mathrm{s}^{-1}\right)$, it is also notable that a similarly higher rate was observed when $\mathrm{R}_{3}=t \mathrm{Bu}$ as previously reported by us $\left(k_{\mathrm{obs}}=58 \times 10^{-6}\right.$ $\left.\mathrm{s}^{-1}\right){ }^{10 b}$ It seems that the substitution at $\mathrm{R}_{3}$ position exerts more of an electronic influence on the aluminium centre, than substitution at sites $\mathrm{R}_{1}$ or $\mathrm{R}_{2}$. The other initiators Al-F and Al-G have comparable rates to the previously reported Al-(A-D). ${ }^{10 b}$ It is notable that compound Al-F has a short lag period at the start of the polymerization, likely owing to a relatively slow formation of the active aluminium alkoxide initiating species.

The titanium complexes, Ti-B, $\mathbf{D}$ and $\mathbf{G}$ were all slow initiators with comparable observed rate constants to the Al initiators $\left(k_{\mathrm{obs}}=1.7-3.7 \times 10^{-6} \mathrm{~s}^{-1}\right)$. It is interesting to note that the rate of polymerisation of Ti-B was faster than Ti-D, the opposite trend to that observed for the aluminium complexes bearing the same ligands. The slower rate of polymerization of compounds Ti-B and Ti-G, versus Ti-D (where $R_{1}=R_{2}=H$ ), could have a steric origin note: limited electronic trends with variation of $R_{1}$ and $R_{2}$ could be identified in the series of related aluminium complexes. The data for the kinetics of Ti-G show a slight deviation from linearity $\left(R^{2}=0.9577\right)$ which is proposed to be due to the relatively long polymerization period and/or slower initiation.

Compounds Al-E, $\mathbf{F}$ and $\mathbf{G}$ exhibited a high degree of polymerization control, with all initiators showing a linear evolution of molecular weight with percentage conversion, $M_{\mathrm{n}}$ 


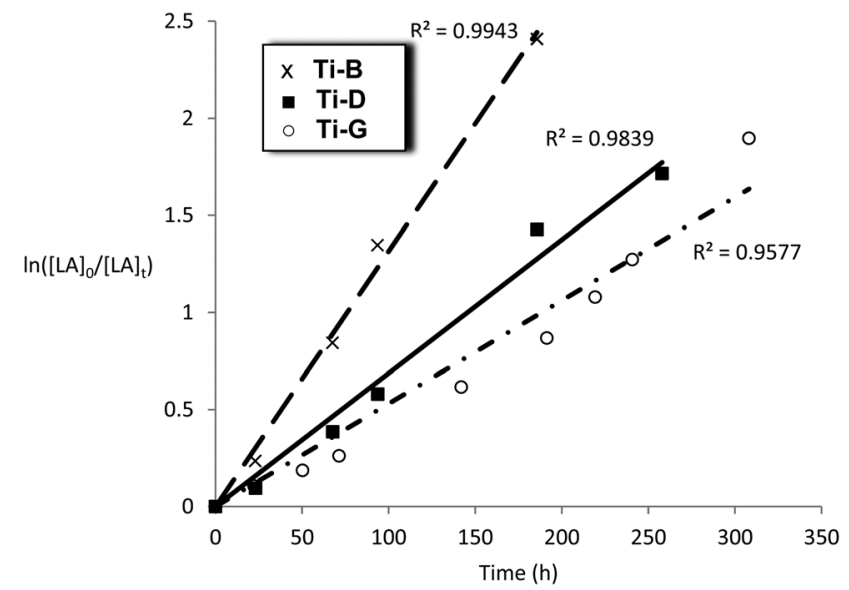

Fig. 10 Plot of $\ln \left([L A]_{0} /[L A]_{t}\right)$ vs. time for initiators Ti-B, D and G Conditions: $[L A]_{0}=1 \mathrm{M}, 1: 100[\mathrm{ll}]$ : [LA], toluene, $348 \mathrm{~K}$.

values being close to those predicted on the basis of the initiator concentration and dispersities are narrow throughout the course of the polymerizations $(<1.11$ in all cases). This level of polymerization control is comparable to the previously reported bis(8-quinolinolato)aluminium ethyl compounds and the bis(8-quinolinolato)gallium tert-butoxide compounds. ${ }^{10 a, b}$ The polymer end-groups were analysed using MALDI-ToF mass spectrometry, which showed that the major series were chain end-capped with iso-propyl ester groups (Fig. S18†). Compounds Ti-B, $\mathbf{D}$ and $\mathbf{G}$ also show a linear evolution of number averaged molecular weight $\left(M_{\mathrm{n}}\right)$ and narrow dispersities. The $M_{\mathrm{n}}$ values were consistent with two polymer chains growing from the two alkoxide initiating groups on the titanium catalysts (Table 2). This is rather different to the aluminium catalysts where a single polymer chain grows (for the single alkyl site). Thus, although equivalent rates are exhibited per equivalent of metal, the rate of the aluminium per active site is likely faster (approximately twice as fast).

The $\mathrm{Al}$ and Ti initiators all exert an isotactic bias during the polymerization of $r a c$-LA. It is observed that the initiators with the most sterically hindered substituents at the $\mathrm{R}_{1}$ position result in higher degrees of iso-selectivity, i.e. Al-A, Al-B and Al-F. For the new initiators the best iso-selectivity is observed for Al-F $\left(P_{\mathrm{i}}=0.75\right)$, with a phenyl substituent at $\mathrm{R}_{\mathbf{1}}$. Attempts to prepare related ligands with more sterically hindered substituents at $\mathrm{R}_{1}$ were unsuccessful due to problems with ligand synthesis/purification. The analysis of the isotactic PLA produced by Al-F indicates that an enantiomorphic site control mechanism is dominant, with the relative integrals of stereoerror signals being: [sis]:[sii]:[iis]:[isi] $=1: 1: 1: 2$ (Fig. S19†). Compared to the $\mathrm{Al}$ analogues, the $\mathrm{Ti}$ complexes show lower iso-selectivities, with the maximum $P_{\mathrm{i}}=0.65$ for Ti-B (Fig. S20†). It should be noted that any degree of iso-selectivity for titanium initiators is rather unusual and this value may represent an interesting opportunity to prepare more selective titanium initiators in the future. ${ }^{17}$ In contrast, there have been several previous examples of hetero-selective titanium initiators and in such cases, the selectivity has been improved using heavier Group (Iv) complexes, i.e. of $\mathrm{Zr}(\mathrm{Iv})$ or $\mathrm{Hf}(\mathrm{Iv}) .^{9 d-f, i j, 18}$

Polymerizations were also conducted using the $\mathrm{Zn}$ initiators, either in methylene dichloride or THF solutions at $298 \mathrm{~K}$ (Table 3).

The polymerization kinetics were monitored for each initiator and show a first order dependence on lactide concentration in every case. The pseudo first-order rate constants, $k_{\text {obs }}$, were determined when the polymerization was conducted in either THF (Fig. 11) or methylene dichloride (Fig. 12). In contrast to the $\mathrm{Al}$ initiators which require thermal activation, the $\mathrm{Zn}$ initiators are all active at $298 \mathrm{~K}$. It may be that for the $\mathrm{Al}$ initiators, the higher temperatures are required to accelerate the formation of the active aluminium alkoxide species, whereas for the zinc initiators the reaction between alcohol and zinc-ethyl occurs without heating. Such a proposal is supported by the reduced bond dissociation energy of zinccarbon bonds, $\mathrm{Zn}-\mathrm{C}_{2} \mathrm{H}_{5} 201 \mathrm{~kJ} \mathrm{~mol}^{-1}$, compared to aluminium-carbon bonds, Al-C $255 \mathrm{~kJ} \mathrm{~mol}^{-1}{ }^{19}$

The polymerizations in THF exhibited a significant induction period ( 1-2 hours), after which the polymerizations pro-

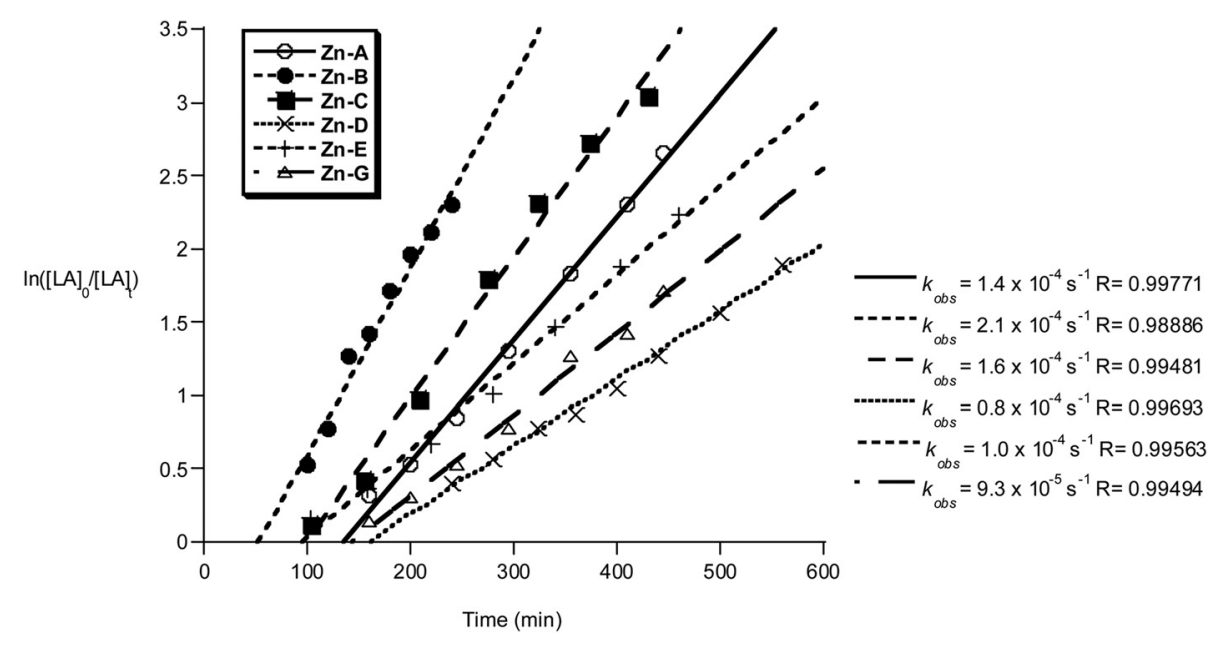

Fig. 11 Plot of $\ln \left([L A]_{0} /[L A]_{t}\right)$ vs. time of initiator Zn-A-E and G. Conditions: $[L A]_{0}=1 \mathrm{M}, 1: 1: 100[\mathrm{ll}]:[\mathrm{iPrOH}]:[\mathrm{LA}], \mathrm{THF}, 298 \mathrm{~K}$. 


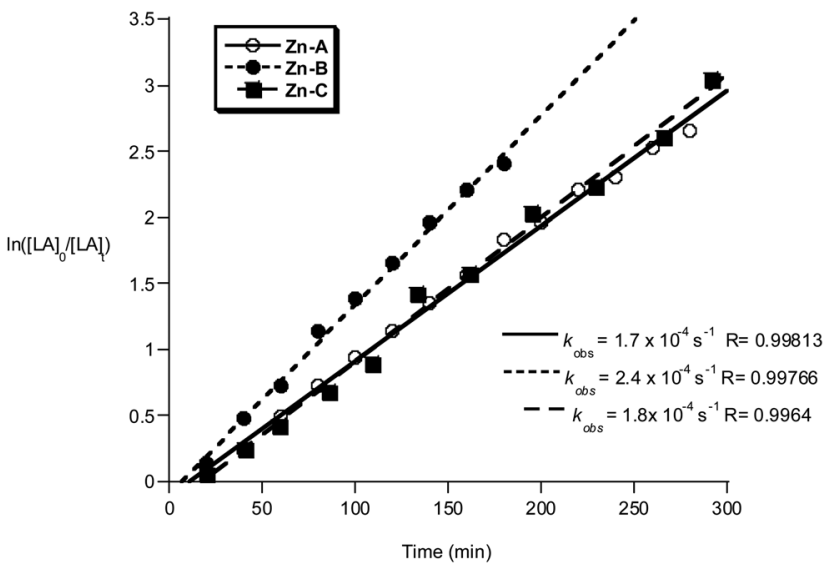

Fig. 12 Plot of $\ln \left([L A]_{0} /[L A]_{t}\right)$ vs. time of initiators $\mathrm{Zn}-\mathrm{A}, \mathrm{B}$ and C. Conditions: [LA $]_{0}=1 \mathrm{M}, 1: 1: 100$ [I] : [iPrOH] : [LA], $\mathrm{CH}_{2} \mathrm{Cl}_{2}, 298 \mathrm{~K}$.

gressed with good control and showed pseudo first-order kinetics. Interestingly, when methylene dichloride was employed as a solvent, the induction period was not observed. It is proposed that during the induction period, the active alkoxide initiator is forming and that THF coordination may slow the rate of $\mathrm{Zn}-\mathrm{C}$ alcoholysis. During the propagation phases the rates of polymerization are not significantly influenced by the reaction solvent, with comparable values for $k_{\text {obs }}$ being obtained (Zn-A: $k_{\text {obs }}=1.4 \times 10^{-4} \mathrm{~s}^{-1}$ in THF and $k_{\text {obs }}=1.7 \times$ $10^{-4} \mathrm{~s}^{-1}$ in methylene chloride). The polymerization activity of compounds Zn-D, Zn-E and Zn-G in methylene dichloride were not monitored, due to the reduced solubility of the initiator in that solvent.

The zinc compounds were moderately fast initiators, reacting in the order Zn-B $>$ Zn-C $>$ Zn-A $>$ Zn-E $>$ Zn-G $>$ Zn-D. Compounds Zn-A, Zn-B and Zn-C (where $\mathrm{R}_{1}=\mathrm{R}_{2}=\mathrm{Cl}, \mathrm{R}_{1}=\mathrm{I} \mathrm{R}_{2}$ $=\mathrm{Cl}$ and $\mathrm{R}_{1}=\mathrm{R}_{2}=\mathrm{Br}$, respectively) were the fastest, with a clear trend in rate with respect to the halide substituent $\mathrm{I}>\mathrm{Br}>\mathrm{Cl}$ and with the Lewis acidity of the active site. In contrast to the results using $\mathrm{Al}$ initiators, compound $\mathbf{Z n - E}\left(\mathrm{R}_{3}=\mathrm{Ph}\right)$, is slightly slower than the other $\mathrm{Zn}$ initiators. This suggests that different factors govern the activity of the two types of metal initiator. A comparison of the activity of these $\mathrm{Zn}$ initiators with other known literature systems reveals them to be of good rate (for $\mathrm{Zn}$ compounds). They show equivalent activity to Schiff base zinc complexes and zinc guanidinate complexes. ${ }^{20}$ They are faster than zinc ketoiminate compounds (1:100 I : [LA], $298 \mathrm{~K}$, chloroform, $24 \mathrm{~h}, 100 \%$ ), which also contain a quinolinolate ligand system. ${ }^{21}$ However, compared to the very best zinc catalysts, based on phenolate diamines/diimines, the activities of these $\mathrm{Zn}$ compounds are significantly lower. ${ }^{22}$

All the $\mathrm{Zn}$ initiators show a linear evolution of $M_{\mathrm{n}}$ with percentage conversion, and the dispersities are narrow throughout the polymerizations ( $<1.10$ in all cases). The polymer molecular weights were compared using different size exclusion chromatographic methods, either as an absolute value using light scattering, or $v s$. polystyrene standards (with correction factors applied) or by ${ }^{1} \mathrm{H}$ NMR analysis (by comparison of the signals for the main chain vs. the iso-propoxide end group). In all cases the values are slightly lower than expected. There is no significant initiation from the quinolinolate moieties on the ligand, as determined by ${ }^{1} \mathrm{H}$ NMR and MALDI-ToF analysis of the PLA end-groups. The end group analysis using MALDI-ToF mass spectrometry, showed just one major series in which the chains were end-capped with iso-propyl ester groups and the peaks are separated by 144 amu, consistent with only limited inter-molecular transesterification occurring (Fig. S21†).

Compounds Zn-A-E and $\mathbf{G}$ polymerize rac-LA with a slight heterotactic bias, maximum $P_{\mathrm{S}}=0.70$ (Fig. S22 $\dagger$ ). The degree of stereocontrol does not change as the substituents at the $\mathrm{R}_{1}$ position are altered, this is in contrast to the ability to use this site to 'tune' the iso-selectivity of the Al initiators. Slightly increased hetero-selectivity was observed when the polymerizations are conducted in THF vs. methylene dichloride, $P_{\mathrm{s}}=$ 0.66 vs. 0.60 for both compounds Zn-A, B and C. This improvement in stereocontrol when THF is employed as a solvent has been observed for many other initiating systems. ${ }^{23}$ It has been postulated that the labile coordination of THF to the Lewis acidic metal centres facilitates the hetero-selectivity. ${ }^{23 a, 24}$

\section{Conclusions}

This study investigated the preparation of a series of new compounds of various 8-hydroxyquinoline ligands with earthabundant metals, including $\mathrm{Al}(\mathrm{III}), \mathrm{Ti}(\mathrm{IV})$ and $\mathrm{Zn}$ (II). The proligands contained different substituents at positions ortho$\left(\mathrm{R}_{1}\right)$ and para $\left(\mathrm{R}_{2}\right)$ to the phenolate and ortho- $\left(\mathrm{R}_{3}\right)$ to the $\mathrm{N}$ moieties. The coordination chemistry resulted in the formation of bis(8-quinolinolato)aluminium ethyl, bis(8-quinolinolato) bis(iso-propoxide) titanium(Iv) and (8-quinolinolato)zinc(II) ethyl complexes which were characterized using spectroscopy, elemental analysis and, in some cases, using single crystal X-ray diffraction experiments. In the case of $\mathrm{Al}$ complexes, the coordination geometries were distorted trigonal bipyramidal, with the $\mathrm{N}$-atoms occupying the axial sites. In the case of the zinc complexes, dimeric or higher order aggregates (trimer) were formed depending on the ligand substitution.

All the new complexes were active initiators, in the cases of metal alkyl complexes in combination with exogenous alcohol, for lactide polymerization. The $\mathrm{Al}$ and $\mathrm{Ti}$ initiators showed similar rates which were typical for those particular metal centres. The $\mathrm{Zn}$ initiators, which operated under milder conditions, showed good rates which were significantly (qualitatively) faster than the $\mathrm{Al} / \mathrm{Ti}$ analogues. In terms of the ligand substitution influences over the polymerization rates, the $\mathrm{Al}$ complexes showed significantly faster rates if the position ortho to the $\mathrm{N}$ atom, on the ligand, was substituted with a sterically hindered group. In contrast, for the $\mathrm{Zn}$ initiators no such effect was observable. The complexes all exerted high degrees of polymerization control, leading to PLA of predictable $M_{\mathrm{n}}$ with narrow dispersity $(<1.11$ in all cases). Furthermore, the $\mathrm{Al}$ and Ti initiators exhibited moderate iso-selectivities $\left(P_{\mathrm{i}}=0.75\right)$ 
whilst the $\mathrm{Zn}$ initiators showed a moderate hetero-selectivities $\left(P_{\mathrm{S}}=0.70\right)$.

This series of complexes demonstrates the potential and versatility of the 8-hydroxyquinoline ligand type; ligands which can be easily prepared and offer multiple sites for substitution. The experiments demonstrate the potential for good control, moderate rates and, in some cases, stereocontrol using this ligand class and earth-abundant metals. The influence of the metal coordination spheres over rate and stereochemistry differs from $\mathrm{Al} / \mathrm{Ti}$ to $\mathrm{Zn}$ and this warrants further investigation in the future to help to understand the critical factors to prepare improved catalysts.

\section{Experimental section}

All reactions were conducted under an inert nitrogen atmosphere, using a nitrogen filled glovebox or standard Schlenk techniques. The pro-ligands A-D were prepared as previously described, ${ }^{10 b}$ whilst the experimental protocols for pro-ligands E-G are reported in the ESI. $\dagger$ All solvents and reagents were obtained from commercial sources. Triethyl aluminium and diethyl zinc were obtained from Strem and titanium(Iv) tetrakis(iso-propoxide) was obtained from Sigma-Aldrich. Toluene and THF was distilled from sodium, de-gassed and stored under nitrogen. Methylene dichloride was distilled from $\mathrm{CaH}_{2}$. Isopropyl alcohol was heated to reflux over $\mathrm{CaH}_{2}$, distilled onto fresh $\mathrm{CaH}_{2}$ and further refluxed, then distilled, degassed and stored under nitrogen. Benzene- $d_{6}$ was distilled from sodium, THF- $d_{8}$, toluene- $d_{8}$ and $\mathrm{CDCl}_{3}$ were dried over $\mathrm{CaH}_{2}$, and all were then degassed and stored under nitrogen. rac-Lactide was obtained from Purac Plc. and was crystallised from dry toluene and sublimed at $323 \mathrm{~K}$ three times under vacuum.

Nuclear magnetic resonance (NMR) spectra were recorded on a Bruker Av400 spectrometer operating at $400 \mathrm{MHz}$ for ${ }^{1} \mathrm{H}$ and $100 \mathrm{MHz}$ for ${ }^{13} \mathrm{C}\left\{{ }^{1} \mathrm{H}\right\}$ spectra. Solvent peaks were used as internal references for ${ }^{1} \mathrm{H}$ and ${ }^{13} \mathrm{C}$ chemical shifts (ppm). Higher resolution ${ }^{1} \mathrm{H}$ NMR and ${ }^{1} \mathrm{H}\left\{{ }^{1} \mathrm{H}\right\}$ NMR (homo-decoupled spectroscopy) experiments were performed on a Bruker Av500 spectrometer and also a DRX 400 spectrometer by Mr Peter Haycock. Spectra were processed and analyzed using Mestrenova software. MALDI-ToF mass spectra were performed on a Waters/Micromass MALDI micro MX, using potassium or sodium salts for ionization. Elemental analyses were determined by Mr Stephen Boyer at London Metropolitan University, Science Centre, 29 Hornsey Road, London N7 7DD. GPC-MALLS measurements were conducted on a Polymer Laboratories PL GPC-50 instrument at $35{ }^{\circ} \mathrm{C}$, using two Polymer Laboratories Mixed D columns in series and THF as the

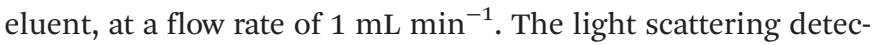
tor was a Dawn 8, Wyatt Technology, and data were analysed using Astra V version 5.3.4.18.

\section{Aluminium complexes}

Triethyl aluminium (53 mg, $0.46 \mathrm{mmol})$ in toluene $(5 \mathrm{~mL})$ was added, drop-wise with stirring, to a solution of the desired 8-hydroxyquinoline $(0.93 \mathrm{mmol})$ in toluene $(10 \mathrm{~mL})$. The reaction was stirred for $12 \mathrm{~h}$, after which time the solvent was removed in vacuo. The resulting solid was washed with hexane, filtered, and dried in vacuo to yield a yellow powder.

Compound Al-E. ${ }^{1} \mathrm{H}$ NMR $\left(500 \mathrm{MHz}, \mathrm{THF}-d_{8}\right) \delta(\mathrm{ppm}): 8.49$ $\left(\mathrm{d}, 2 \mathrm{H}, \mathrm{CH},{ }^{3} J_{H H}=8.5 \mathrm{~Hz}\right), 8.26\left(\mathrm{dt}, 4 \mathrm{H}, \mathrm{CH},{ }^{3} J_{H H}=7.0 \mathrm{~Hz},{ }^{4} J_{H H}\right.$ $=1.7 \mathrm{~Hz}), 7.75\left(\mathrm{~d}, 2 \mathrm{H}, \mathrm{CH},{ }^{3} J_{H H}=8.5 \mathrm{~Hz}\right), 7.48\left(\mathrm{t}, 2 \mathrm{H}, \mathrm{CH},{ }^{3} J_{H H}\right.$ $=8.2 \mathrm{~Hz}), 7.40\left(\mathrm{~m}, 6 \mathrm{H}, \mathrm{CH}(4 \mathrm{H}), \mathrm{CH}^{(2 \mathrm{H})}\right), 7.24\left(\mathrm{dd}, 2 \mathrm{H}, \mathrm{CH},{ }^{3} J_{H H}=\right.$ $\left.8.2 \mathrm{~Hz},{ }^{4} J_{H H}=1.2 \mathrm{~Hz}\right), 7.04\left(\mathrm{dd}, 2 \mathrm{H}, \mathrm{CH},{ }^{3} J_{H H}=7.5 \mathrm{~Hz},{ }^{4} J_{H H}=\right.$ $1.2 \mathrm{~Hz}),-0.21\left(\mathrm{t}, 3 \mathrm{H}, \mathrm{CH}_{2} \mathrm{CH}_{3},{ }^{3} J_{H H}=8.0 \mathrm{~Hz}\right),-1.08(\mathrm{dq}, 2 \mathrm{H}$, $\left.\mathrm{CH}_{2} \mathrm{CH}_{3},{ }^{3} J_{H H}=8.0 \mathrm{~Hz},{ }^{4} J_{H H}=2.0 \mathrm{~Hz}\right) ;{ }^{13} \mathrm{C}\left\{{ }^{1} \mathrm{H}\right\} \mathrm{NMR}$ $\left(100 \mathrm{MHz}\right.$, THF- $\left.d_{8}\right) \delta(\mathrm{ppm}): 159.4\left(\mathrm{C}^{\mathrm{IV}}\right), 158.6\left(\mathrm{C}^{\mathrm{IV}}\right), 141.5$ $\left(\mathrm{C}^{\mathrm{IV}}\right), 140.5\left(\mathrm{C}^{\mathrm{IV}}\right), 140.2(\mathrm{CH}), 131.2(\mathrm{CH}), 131.2(\mathrm{CH}), 130.8$ $(\mathrm{CH}), 130.1(\mathrm{CH}), 129.4\left(\mathrm{C}^{\mathrm{IV}}\right), 129.2(\mathrm{CH}), 125.0(\mathrm{CH}), 114.5$ $(\mathrm{CH}), \quad 113.9(\mathrm{CH}), \quad 9.3 \quad\left(\mathrm{CH}_{3}\right), \quad 1.8 \quad\left(\mathrm{CH}_{2}\right) ;$ Anal. Calc. $\left(\mathrm{AlC}_{32} \mathrm{H}_{25} \mathrm{~N}_{2} \mathrm{O}_{2}\right)$ : C, 77.40; H, 5.07; N, 5.64 Found: C, 77.48; H, $5.20 ; \mathrm{N}, 5.68$.

Compound Al-F. ${ }^{1} \mathrm{H}$ NMR $\left(400 \mathrm{MHz}\right.$, benzene- $\left.d_{6}\right) \delta(\mathrm{ppm})$ : $7.97\left(\mathrm{~d}, 2 \mathrm{H}, \mathrm{CH},{ }^{3} J_{H H}=8.6 \mathrm{~Hz}\right), 7.74\left(\mathrm{~d}, 2 \mathrm{H}, \mathrm{CH},{ }^{3} J_{H H}=8.6 \mathrm{~Hz}\right)$, $7.63(\mathrm{~s}, 2 \mathrm{H}, \mathrm{CH}), 7.18-7.29(\mathrm{~m}, 8 \mathrm{H}, \mathrm{CH}), 6.56\left(\mathrm{~d}, 2 \mathrm{H}, \mathrm{CH},{ }^{3} J_{H H}=\right.$ $8.6 \mathrm{~Hz}), 2.80\left(\mathrm{~s}, 6 \mathrm{H}, \mathrm{CH}_{3}\right), 1.05\left(\mathrm{t}, 3 \mathrm{H}, \mathrm{CH}_{2} \mathrm{CH}_{3},{ }^{3} J_{H H}=8.13 \mathrm{~Hz}\right)$, 0.50-0.62, $0.30-0.43 \quad\left(\mathrm{~m}, \quad 2 \mathrm{H}, \quad \mathrm{CH}_{2} \mathrm{CH}_{3}\right) ;{ }^{13} \mathrm{C} \quad\left\{{ }^{1} \mathrm{H}\right\} \quad \mathrm{NMR}$ $\left(100 \mathrm{MHz}\right.$, benzene- $\left.d_{6}\right) \delta(\mathrm{ppm}): 157.6\left(\mathrm{C}^{\mathrm{IV}}\right), 153.95\left(\mathrm{C}^{\mathrm{IV}}\right), 141.1$ $\left(\mathrm{C}^{\mathrm{IV}}\right), 138.5\left(\mathrm{C}^{\mathrm{IV}}\right), 135.7(\mathrm{CH}), 130.0(\mathrm{CH}), 129.9(\mathrm{CH}), 127.8$ $(\mathrm{CH}), 127.1(\mathrm{CH}), 125.4\left(\mathrm{C}^{\mathrm{IV}}\right), 124.4\left(\mathrm{C}^{\mathrm{IV}}\right), 124.1(\mathrm{CH}), 116.9$ $\left(\mathrm{C}^{\mathrm{IV}}\right), 23.2\left(\mathrm{CH}_{3}\right), 9.9\left(\mathrm{CH}_{2} \mathrm{CH}_{3}\right), 1.4\left(\mathrm{CH}_{2} \mathrm{CH}_{3}\right)$; Anal. Calc. $\left(\mathrm{C}_{34} \mathrm{H}_{27} \mathrm{AlCl}_{2} \mathrm{~N}_{2} \mathrm{O}_{2}\right)$ : C, 68.81; H, 4.59; N, 4.72 Found: C, 68.60; $\mathrm{H}, 4.71 ; \mathrm{N}, 4.82$.

Compound Al-G. ${ }^{1} \mathrm{H}$ NMR (400 MHz, THF- $\left.d_{8}\right) \delta$ (ppm): 8.59 $\left(\mathrm{d}, 2 \mathrm{H}, \mathrm{CH},{ }^{3} J_{H H}=8.8 \mathrm{~Hz}\right), 7.79\left(\mathrm{~d}, 2 \mathrm{H}, \mathrm{CH},{ }^{3} J_{H H}=8.8 \mathrm{~Hz}\right), 7.57$ $(\mathrm{s}, 2 \mathrm{H}, \mathrm{CH}), 4.49\left(\mathrm{t}, 4 \mathrm{H},(\mathrm{Cp}(\mathrm{CH}) \mathrm{C} \equiv \mathrm{C}),{ }^{3} \mathrm{~J}_{\mathrm{HH}}=2.0 \mathrm{~Hz}\right), 4.27(\mathrm{t}$, $\left.4 \mathrm{H},(\mathrm{Cp}(\mathrm{CH}) \mathrm{C} \equiv \mathrm{C}),{ }^{3} J_{H H}=2.0 \mathrm{~Hz}\right), 4.19(\mathrm{~s}, 10 \mathrm{H}, \mathrm{Cp}(\mathrm{CH})), 3.34$ $\left(\mathrm{s}, 6 \mathrm{H}, \mathrm{CH}_{3}\right), 0.67\left(\mathrm{t}, 3 \mathrm{H}, \mathrm{CH}_{3}, J_{H H}=8.0 \mathrm{~Hz}\right), 0.11(\mathrm{dq}, 2 \mathrm{H}$, $\left.\mathrm{CH}_{2},{ }^{3} J_{H H}=8.0 \mathrm{~Hz},{ }^{4} J_{H H}=14.6 \mathrm{~Hz}\right) ;{ }^{13} \mathrm{C}\left\{{ }^{1} \mathrm{H}\right\}$ NMR $(100 \mathrm{MHz}$, toluene- $\left.d_{8}\right) \delta(\mathrm{ppm}): 158.8\left(\mathrm{C}^{\mathrm{IV}}\right), 158.2\left(\mathrm{C}^{\mathrm{IV}}\right), 140.5\left(\mathrm{C}^{\mathrm{IV}}\right), 135.8$ $(\mathrm{CH}), 131.0(\mathrm{CH}), 124.7\left(\mathrm{C}^{\mathrm{IV}}\right), 124.6(\mathrm{CH}), 116.2\left(\mathrm{C}^{\mathrm{IV}}\right), 109.1$ $\left(\mathrm{C}^{\mathrm{IV}}\right), 93.7(\mathrm{C} \equiv \mathrm{C}), 83.7(\mathrm{C} \equiv \mathrm{C}), 71.7(\mathrm{Cp}(\mathrm{CH}) \mathrm{C} \equiv \mathrm{C}), 70.3(\mathrm{Cp}-$ $(\mathrm{CH})), 69.8(\mathrm{Cp}(\mathrm{CH}) \mathrm{C} \equiv \mathrm{C}), 66.8\left(\mathrm{Cp}\left(\mathrm{C}^{\mathrm{IV}}\right) \mathrm{C} \equiv \mathrm{C}\right), 23.3\left(\mathrm{CH}_{3}\right), 9.9$ $\left(\mathrm{CH}_{2} \mathrm{CH}_{3}\right), 1.4\left(\mathrm{CH}_{2} \mathrm{CH}_{3}\right)$; Anal. Calc. $\left(\mathrm{AlC}_{46} \mathrm{H}_{35} \mathrm{Cl}_{2} \mathrm{Fe}_{2} \mathrm{~N}_{2} \mathrm{O}_{2}\right)$ : C, $64.44 ; \mathrm{H}, 4.11$; N, 3.27 Found: C, 64.35; H, 4.05; N, 3.27.

\section{Titanium complexes}

Titanium(Iv) tetrakis(iso-propoxide) $(0.23 \mathrm{~mL}, 0.80 \mathrm{mmol})$ in toluene $(15 \mathrm{~mL})$ was added, drop-wise under nitrogen, to a solution of the 8-hydroxyquinoline $(1.6 \mathrm{mmol})$ in toluene $(15 \mathrm{~mL})$, with stirring. The clear yellow solution was left to stir for $12 \mathrm{~h}$ at $298 \mathrm{~K}$. The solvent was removed in vacuo and the product washed with hexane $(10 \mathrm{~mL})$ and isolated as a yellow solid.

Compound Ti-B. ${ }^{1} \mathrm{H}$ NMR (400 MHz, chloroform- $d$ ) $\delta$ (ppm): $8.24\left(\mathrm{~d}, 2 \mathrm{H}, \mathrm{CH},{ }^{3} J_{H H}=8.7 \mathrm{~Hz}\right), 7.86(\mathrm{~s}, 2 \mathrm{H}, \mathrm{CH}), 7.17$ $\left(\mathrm{d}, 2 \mathrm{H}, \mathrm{CH},{ }^{3} J_{H H}=8.7 \mathrm{~Hz}\right), 5.02(\mathrm{sept}, 2 \mathrm{H}, \mathrm{CH}), 2.82(\mathrm{~s}, 6 \mathrm{H}$, $\left.\mathrm{CH}_{3}\right), 1.28\left(\mathrm{dd}, 12 \mathrm{H}, \mathrm{CH}_{3}\right) ;{ }^{13} \mathrm{C}\left\{{ }^{1} \mathrm{H}\right\}$ NMR $(100 \mathrm{MHz}$, chloroform- $d) \delta(\mathrm{ppm}): 160.8\left(\mathrm{C}^{\mathrm{IV}}\right), 160.3\left(\mathrm{C}^{\mathrm{IV}}\right), 140.6\left(\mathrm{C}^{\mathrm{IV}}\right), 135.3$ $(\mathrm{CH}), 134.9(\mathrm{CH}), 125.2\left(\mathrm{C}^{\mathrm{IV}}\right), 125.01(\mathrm{CH}), 117.6\left(\mathrm{C}^{\mathrm{IV}}\right), 80.6$ $(\mathrm{CH}), \quad 79.4 \quad\left(\mathrm{C}^{\mathrm{IV}}\right), \quad 26.6\left(\mathrm{CH}_{3}\right), \quad 24.1\left(\mathrm{CH}_{3}\right) ; \quad$ Anal. Calc. 
$\left(\mathrm{C}_{26} \mathrm{H}_{26} \mathrm{Cl}_{2} \mathrm{I}_{2} \mathrm{~N}_{2} \mathrm{O}_{4} \mathrm{Ti}\right): \mathrm{C}, 38.89 \% ; \mathrm{H}, 3.26 \%$; N, 3.49\%. Found: C, 38.68\%; H, 3.17\%; N, 3.42\%.

Compound Ti-D. ${ }^{1} \mathrm{H}$ NMR (400 MHz, benzene- $\left.d_{6}\right) \delta(\mathrm{ppm})$ : $7.24\left(\mathrm{t}, 2 \mathrm{H}, \mathrm{CH},{ }^{3} J_{H H}=8.0 \mathrm{~Hz}\right), 7.15\left(\mathrm{~d}, 2 \mathrm{H}, \mathrm{CH},{ }^{3} J_{H H}=8.7 \mathrm{~Hz}\right)$, $7.05\left(\mathrm{dd}, 2 \mathrm{H}, \mathrm{CH},{ }^{3} J_{H H}=7.6 \mathrm{~Hz},{ }^{4} \mathrm{~J}_{\mathrm{HH}}=1.2 \mathrm{~Hz}\right), 6.75(\mathrm{dd}, 2 \mathrm{H}$, $\left.\mathrm{CH},{ }^{3} J_{H H}=8.0 \mathrm{~Hz},{ }^{4} J_{H H}=0.8 \mathrm{~Hz}\right), 6.30\left(\mathrm{~d}, 2 \mathrm{H}, \mathrm{CH},{ }^{3} J_{H H}=8.4\right.$ $\mathrm{Hz}$ ), 5.10 (sept, 2H, CH, $\left.{ }^{3} J_{H H}=6.0 \mathrm{~Hz}\right), 2.94\left(\mathrm{~s}, 6 \mathrm{H}, \mathrm{CH}_{3}\right), 1.31$ (dd, $\left.12 \mathrm{H}, \mathrm{CH}_{3},{ }^{3} J_{H H}=6.0 \mathrm{~Hz}\right) ;{ }^{13} \mathrm{C}\left\{{ }^{1} \mathrm{H}\right\}$ NMR (100 MHz, chloroform- $d) \delta(\mathrm{ppm}): 161.3\left(\mathrm{C}^{\mathrm{IV}}\right), 158.7\left(\mathrm{C}^{\mathrm{IV}}\right), 142.5\left(\mathrm{C}^{\mathrm{IV}}\right), 137.1$ $(\mathrm{CH}), 127.8(\mathrm{CH}), 127.6\left(\mathrm{C}^{\mathrm{IV}}\right), 123.9(\mathrm{CH}), 114.6(\mathrm{CH}), 111.7$ $(\mathrm{CH}), \quad 79.0(\mathrm{CH}), \quad 25.4\left(\mathrm{CH}_{3}\right), 23.2\left(\mathrm{CH}_{3}\right)$; Anal. Calc. $\left(\mathrm{C}_{26} \mathrm{H}_{30} \mathrm{~N}_{2} \mathrm{O}_{4} \mathrm{Ti}\right): \mathrm{C}, 64.74 \% ; \mathrm{H}, 6.27 \% ; \mathrm{N}, 5.81 \%$. Found: $\mathrm{C}$, $64.66 \% ; \mathrm{H}, 6.34 \%$; N, 5.69\%.

Compound Ti-G. ${ }^{1} \mathrm{H}$ NMR (400 MHz, benzene- $\left.d_{6}\right) \delta(\mathrm{ppm})$ : $7.68(\mathrm{~s}, 1 \mathrm{H}, \mathrm{CH}), 7.64\left(\mathrm{~d}, 1 \mathrm{H}, \mathrm{CH},{ }^{3} J_{H H}=8.4 \mathrm{~Hz}\right), 6.26(\mathrm{~d}, 1 \mathrm{H}$, $\left.\mathrm{CH},{ }^{3} J_{H H}=8.4 \mathrm{~Hz}\right), 5.19\left(\mathrm{sept}, 2 \mathrm{H}, \mathrm{CH},{ }^{3} J_{H H}=6 \mathrm{~Hz}\right), 4.62(\mathrm{~m}$, 2H, Cp $(\mathrm{CH})), 4.25$ (s, 5H, Cp $(\mathrm{CH})), 4.05(\mathrm{~m}, 2 \mathrm{H}, \mathrm{Cp}(\mathrm{CH})), 3.06$ (s, $3 \mathrm{H}, \mathrm{CH}_{3}$ ), 1.49 (d, 6H, $\mathrm{CH}_{3},{ }^{3} J_{H H}=6 \mathrm{~Hz}$ ), 1.41 (d, 6H, $\mathrm{CH}_{3}$, $\left.{ }^{3} J_{H H}=6 \mathrm{~Hz}\right) ;{ }^{13} \mathrm{C}\left\{{ }^{1} \mathrm{H}\right\} \mathrm{NMR}(100 \mathrm{MHz}$, chloroform- $d) \delta(\mathrm{ppm})$ : $160.2\left(\mathrm{C}^{\mathrm{IV}}\right), 142.6\left(\mathrm{C}^{\mathrm{IV}}\right), 134.4(\mathrm{CH}), 129.8(\mathrm{CH}), 124.9(\mathrm{CH})$, $124.9\left(\mathrm{C}^{\mathrm{IV}}\right), 116.9\left(\mathrm{C}^{\mathrm{IV}}\right), 107.2\left(\mathrm{C}^{\mathrm{IV}}\right), 93.8\left(\mathrm{C}^{\mathrm{IV}}\right), 83.2(\mathrm{C} \equiv \mathrm{C}), 80.1$ $(\mathrm{C} \equiv \mathrm{C}), 71.4(\mathrm{CH}), 71.3(\mathrm{Cp}(\mathrm{CH})), 70.1(\mathrm{Cp}(\mathrm{CH})), 68.9(\mathrm{Cp}(\mathrm{CH}))$, $66.0(\mathrm{Cp}(C)), 25.6\left(\mathrm{CH}_{3}\right), 23.6\left(\mathrm{CH}_{3}\right)$; Anal. Calc. $\left(\mathrm{C}_{50} \mathrm{H}_{44} \mathrm{Cl}_{2} \mathrm{I}_{2}-\right.$ $\left.\mathrm{N}_{2} \mathrm{O}_{4} \mathrm{Ti}\right): \mathrm{C}, 62.08 \% ; \mathrm{H}, 4.58 \% ; \mathrm{N}, 2.90 \%$. Found: C, 61.93\%; $\mathrm{H}, 4.57 \%$; N, $2.99 \%$.

\section{Zinc complexes}

Diethyl zinc $(0.27 \mathrm{~g}, 2.19 \mathrm{mmol})$ in toluene $(5 \mathrm{~mL})$ was added, dropwise with stirring, to a solution of 8-hydroxyquinoline $(2.19 \mathrm{mmol})$ in toluene $(15 \mathrm{~mL})$. The solution was stirred for $12 \mathrm{~h}$, after which time a yellow precipitate had formed. The precipitate was isolated by filtration, washed with hexane and dried in vacuo to yield a yellow solid.

Compound Zn-A. ${ }^{1} \mathrm{H}$ NMR (400 MHz, THF- $\left.d_{8}\right) \delta$ (ppm): 8.51 $\left(\mathrm{d}, 1 \mathrm{H},{ }^{3} J_{H H}=8.6 \mathrm{~Hz}\right), 7.56\left(\mathrm{~d}, 1 \mathrm{H},{ }^{3} J_{H H}=8.6 \mathrm{~Hz}\right), 7.55(\mathrm{~s}, 1 \mathrm{H})$, $2.84(\mathrm{~s}, 3 \mathrm{H}), 1.31\left(\mathrm{t}, 3 \mathrm{H},{ }^{3} J_{H H}=8.2 \mathrm{~Hz}\right), 0.43\left(\mathrm{q}, 2 \mathrm{H},{ }^{3} J_{H H}=\right.$ $8.2 \mathrm{~Hz}) ;{ }^{13} \mathrm{C}\left\{{ }^{1} \mathrm{H}\right\}$ NMR (125.3 MHz, THF- $\left.d_{8}\right) \delta$ (ppm): 160.0 $\left(\mathrm{C}^{\mathrm{IV}}\right), 157.6\left(\mathrm{C}^{\mathrm{IV}}\right), 141.4\left(\mathrm{C}^{\mathrm{IV}}\right), 137.3(\mathrm{CH}), 130.4(\mathrm{CH}), 125.4$ $\left(\mathrm{C}^{\mathrm{IV}}\right), 123.9(\mathrm{CH}), 118.2\left(\mathrm{C}^{\mathrm{IV}}\right), 112.0\left(\mathrm{C}^{\mathrm{IV}}\right), 24.7\left(\mathrm{CH}_{3}\right), 13.3$ $\left(\mathrm{CH}_{2} \mathrm{CH}_{3}\right),-1.5 \quad\left(\mathrm{CH}_{2} \mathrm{CH}_{3}\right)$; Anal. Calc. $\left(\mathrm{ZnC}_{12} \mathrm{H}_{11} \mathrm{NOCl}_{2}\right)$ : C, 44.83\%; H, 3.45\%; N, 4.36\% Found: C, 44.88\%; H, 3.33\%; $\mathrm{N}, 4.28 \%$.

Compound Zn-B. ${ }^{1} \mathrm{H}$ NMR (400 MHz, THF- $\left.d_{8}\right) \delta$ (ppm): 8.50 (d, $\left.1 \mathrm{H}, \mathrm{CH},{ }^{3} J_{H H}=8.6 \mathrm{~Hz}\right), 7.84(\mathrm{~s}, 1 \mathrm{H}, \mathrm{CH}), 7.59(\mathrm{~d}, 1 \mathrm{H}, \mathrm{CH}$, $\left.{ }^{3} J_{H H}=8.6 \mathrm{~Hz}\right), 2.84\left(\mathrm{~s}, 3 \mathrm{H}, \mathrm{CH}_{3}\right), 1.31\left(\mathrm{t}, 3 \mathrm{H}, \mathrm{CH}_{3},{ }^{3} J_{H H}=8.2\right.$ $\mathrm{Hz}$ ), 0.43 (q, $2 \mathrm{H}, \quad \mathrm{CH}_{2},{ }^{3} J_{H H}=8.2 \mathrm{~Hz}$ ); ${ }^{13} \mathrm{C}\left\{{ }^{1} \mathrm{H}\right\} \mathrm{NMR}$ (125.3 MHz, THF- $\left.d_{8}\right) \delta(\mathrm{ppm}):-1.3\left(\mathrm{CH}_{2} \mathrm{CH}_{3}\right), 13.3\left(\mathrm{CH}_{2} \mathrm{CH}_{3}\right)$, $24.8\left(\mathrm{CH}_{3}\right), 81.9\left(\mathrm{C}^{\mathrm{IV}}\right), 113.2\left(\mathrm{C}^{\mathrm{IV}}\right), 124.2(\mathrm{CH}), 126.4\left(\mathrm{C}^{\mathrm{IV}}\right), 137.5$ $(\mathrm{CH}), 137.5(\mathrm{CH}), 138.8\left(\mathrm{C}^{\mathrm{IV}}\right), 157.7\left(\mathrm{C}^{\mathrm{IV}}\right), 163.7\left(\mathrm{C}^{\mathrm{IV}}\right)$; Anal. Calc. $\left(\mathrm{ZnC}_{12} \mathrm{H}_{11}\right.$ ClINO): C, 34.90\%; H, 2.68\%; N, 3.39\% Found: C, 34.84\%; H, 2.64\%; N, 3.31\%.

Compound Zn-C. ${ }^{1} \mathrm{H}$ NMR (400 MHz, THF- $\left.d_{8}\right) \delta$ (ppm): 8.46 $\left(\mathrm{d}, 1 \mathrm{H}, \mathrm{CH},{ }^{3} J_{H H}=8.4 \mathrm{~Hz}\right), 7.85(\mathrm{~s}, 1 \mathrm{H}, \mathrm{CH}), 7.57(\mathrm{~d}, 1 \mathrm{H}, \mathrm{CH}$, $\left.{ }^{3} J_{H H}=8.4 \mathrm{~Hz}\right), 2.84\left(\mathrm{~s}, 3 \mathrm{H}, \mathrm{CH}_{3}\right), 1.31\left(\mathrm{t}, 3 \mathrm{H}, \mathrm{CH}_{3},{ }^{3} J_{H H}=8.0\right.$ $\mathrm{Hz}), \quad 0.43$ (q, 2H, $\mathrm{CH}_{2},{ }^{3} J_{H H}=8.0 \mathrm{~Hz}$ ); ${ }^{13} \mathrm{C}\left\{{ }^{1} \mathrm{H}\right\} \mathrm{NMR}$ (125.3 MHz, THF- $\left.d_{8}\right) \delta(\mathrm{ppm}): 161.4\left(\mathrm{C}^{\mathrm{IV}}\right), 157.2\left(\mathrm{C}^{\mathrm{IV}}\right), 141.2$
$\left(\mathrm{C}^{\mathrm{IV}}\right), 139.8(\mathrm{CH}), 135.8(\mathrm{CH}), 127.1\left(\mathrm{C}^{\mathrm{IV}}\right), 124.3(\mathrm{CH}), 108.2$ $\left(\mathrm{C}^{\mathrm{IV}}\right), 100.9\left(\mathrm{C}^{\mathrm{IV}}\right), 24.1\left(\mathrm{CH}_{3}\right), 13.3\left(\mathrm{CH}_{2} \mathrm{CH}_{3}\right),-1.4\left(\mathrm{CH}_{2} \mathrm{CH}_{3}\right)$ Anal. Calc. $\left(\mathrm{ZnC}_{12} \mathrm{H}_{11} \mathrm{Br}_{2} \mathrm{NO}\right)$ : C, 35.12\%; H, 2.70\%; N, 3.41\% Found: C, 35.25\%; H, 2.67\%; N, 3.39\%.

Compound Zn-D. ${ }^{1} \mathrm{H}$ NMR (400 MHz, pyridine- $\left.d_{5}\right) \delta(\mathrm{ppm})$ : $8.12\left(\mathrm{~d}, 1 \mathrm{H}, \mathrm{CH},{ }^{3} J_{H H}=8.4 \mathrm{~Hz}\right), 7.58\left(\mathrm{t}, 1 \mathrm{H}, \mathrm{CH},{ }^{3} J_{H H}=8.0 \mathrm{~Hz}\right)$, $7.44\left(\mathrm{dd}, 1 \mathrm{H}, \mathrm{CH},{ }^{3} J_{H H}=8.0 \mathrm{~Hz},{ }^{4} \mathrm{~J}_{\mathrm{HH}}=0.8 \mathrm{~Hz}\right), 7.15(\mathrm{~d}, 1 \mathrm{H}$, CH. $\left.{ }^{3} J_{H H}=8.4 \mathrm{~Hz}\right), 7.03\left(\mathrm{dd}, 1 \mathrm{H}, \mathrm{CH},{ }^{3} J_{H H}=8.0 \mathrm{~Hz},{ }^{3} J_{H H}=0.8\right.$ $\mathrm{Hz}), 2.62\left(\mathrm{~s}, 3 \mathrm{H}, \mathrm{CH}_{3}\right), 1.66\left(\mathrm{t}, 3 \mathrm{H}, \mathrm{CH}_{2} \mathrm{CH}_{3},{ }^{3} J_{H H}=8.0 \mathrm{~Hz}\right), 0.86$ (q, $\left.2 \mathrm{H}, \mathrm{CH}_{2} \mathrm{CH}_{3},{ }^{3} J_{H H}=8.0 \mathrm{~Hz}\right) ;{ }^{13} \mathrm{C}\left\{{ }^{1} \mathrm{H}\right\}$ NMR $(100 \mathrm{MHz}$, THF$\left.\mathrm{d}_{8} ; \delta(\mathrm{ppm})\right): 166.1\left(\mathrm{C}^{\mathrm{IV}}\right), 154.7\left(\mathrm{C}^{\mathrm{IV}}\right), 141.57\left(\mathrm{C}^{\mathrm{IV}}\right), 139.9(\mathrm{CH})$, $130.7(\mathrm{CH}), 129.4\left(\mathrm{C}^{\mathrm{IV}}\right), 122.8\left(\mathrm{C}^{\mathrm{IV}}\right), 114.5(\mathrm{CH}), 114.5(\mathrm{CH})$, $110.2(\mathrm{CH}), 24.8\left(\mathrm{CH}_{3}\right), 14.59\left(\mathrm{CH}_{2} \mathrm{CH}_{3}\right),-1.56\left(\mathrm{CH}_{2} \mathrm{CH}_{3}\right)$; Anal. Calc. $\left(\mathrm{ZnC}_{12} \mathrm{H}_{13} \mathrm{NO}\right): \mathrm{C}, 57.05 \% ; \mathrm{H}, 5.19 \%$; N, 5.54\% Found: C, $57.00 \%$; H, 5.24\%; N, 5.67\%.

Compound Zn-E. ${ }^{1} \mathrm{H}$ NMR (400 MHz, pyridine- $\left.d_{5}\right) \delta(\mathrm{ppm})$ : $8.30\left(\mathrm{~d}, 1 \mathrm{H}, \mathrm{CH},{ }^{3} J_{H H}=8.8 \mathrm{~Hz}\right), 7.76\left(\mathrm{~d}, 2 \mathrm{H}, \mathrm{CH},{ }^{3} J_{H H}=6.8 \mathrm{~Hz}\right.$, $\left.{ }^{4} J_{H H}=2.2 \mathrm{~Hz}\right), 7.66\left(\mathrm{t}, 1 \mathrm{H}, \mathrm{CH},{ }^{3} J_{H H}=8.0 \mathrm{~Hz}\right), 7.58\left(\mathrm{~d}, 1 \mathrm{H},{ }^{3} J_{H H}\right.$ $=8.4 \mathrm{~Hz}), 7.52(\mathrm{~m}, 4 \mathrm{H}, \mathrm{CH}, \mathrm{CH}, \mathrm{CH}), 7.10\left(\mathrm{dd}, 1 \mathrm{H}, \mathrm{CH},{ }^{3} \mathrm{~J}_{H H}=\right.$ $\left.8.0 \mathrm{~Hz},{ }^{4} \mathrm{~J}_{\mathrm{HH}}=1.0 \mathrm{~Hz}\right), 1.34\left(\mathrm{t}, 3 \mathrm{H}, \mathrm{CH}_{2} \mathrm{CH}_{3},{ }^{3} \mathrm{~J}_{\mathrm{HH}}=8.0 \mathrm{~Hz}\right), 0.64$ (q, $\left.2 \mathrm{H}, \mathrm{CH}_{2} \mathrm{CH}_{3},{ }^{3} J_{H H}=8.2 \mathrm{~Hz}\right) ;{ }^{13} \mathrm{C}\left\{{ }^{1} \mathrm{H}\right\}$ NMR (100 MHz, THF$\left.d_{8} ; \delta(\mathrm{ppm})\right): 164.0\left(\mathrm{C}^{\mathrm{IV}}\right), 155.7\left(\mathrm{C}^{\mathrm{IV}}\right), 141.5\left(\mathrm{C}^{\mathrm{IV}}\right), 140.8(C \mathrm{H})$, $139.6\left(\mathrm{C}^{\mathrm{IV}}\right), 131.0(\mathrm{CH}), 130.5\left(\mathrm{C}^{\mathrm{IV}}\right), 129.2(\mathrm{CH}), 128.9(\mathrm{CH})$, 128.4 (CH), $121.3(\mathrm{CH}), 115.1(\mathrm{CH}), 111.0(\mathrm{CH}), 12.8\left(\mathrm{CH}_{2} \mathrm{CH}_{3}\right)$, $7.2\left(\mathrm{CH}_{2} \mathrm{CH}_{3}\right)$; Anal. Calc. $\left(\mathrm{ZnC}_{17} \mathrm{H}_{15} \mathrm{NO}\right): \mathrm{C}, 64.88 \% ; \mathrm{H}, 4.80 \%$; N, 4.45\% Found: C, $64.75 \%$; H, 4.82\%; N, 4.50\%.

Compound Zn-G. ${ }^{1} \mathrm{H}$ NMR (400 MHz, THF- $\left.d_{8}\right) \delta$ (ppm): 8.48 (d, $\left.1 \mathrm{H}, \mathrm{CH},{ }^{3} J_{H H}=8.6 \mathrm{~Hz}\right), 7.54\left(\mathrm{~d}, 1 \mathrm{H}, \mathrm{CH},{ }^{3} J_{H H}=8.6 \mathrm{~Hz}\right), 7.49$ $(\mathrm{s}, 1 \mathrm{H}, \mathrm{CH}), 4.50\left(\mathrm{t}, 2 \mathrm{H},(\mathrm{Cp}(\mathrm{CH}) \mathrm{C} \equiv \mathrm{C}),{ }^{3} J_{H H}=1.6 \mathrm{~Hz}\right), 4.24(\mathrm{~s}$, $5 \mathrm{H},(\mathrm{Cp}(\mathrm{CH})), 4.21\left(\mathrm{t}, 2 \mathrm{H},(\mathrm{Cp}(\mathrm{CH}) \mathrm{C} \equiv \mathrm{C}),{ }^{3} J_{H H}=1.6 \mathrm{~Hz}\right), 2.83(\mathrm{~s}$, $\left.3 \mathrm{H}, \mathrm{CH}_{3}\right), 1.33\left(\mathrm{t}, 3 \mathrm{H}, \mathrm{CH}_{2} \mathrm{CH}_{3},{ }^{3} \mathrm{~J}_{\mathrm{HH}}=8.1 \mathrm{~Hz}\right), 0.44(\mathrm{q}, 2 \mathrm{H}$, $\left.\mathrm{CH}_{2} \mathrm{CH}_{3},{ }^{3} J_{H H}=8.1 \mathrm{~Hz}\right) ;{ }^{13} \mathrm{C}\left\{{ }^{1} \mathrm{H}\right\}$ NMR (125.3 MHz, THF- $d_{8}$ ) $\delta$ (ppm): $165.5\left(\mathrm{C}^{\mathrm{IV}}\right), 157.2\left(\mathrm{C}^{\mathrm{IV}}\right), 141.5\left(\mathrm{C}^{\mathrm{IV}}\right), 137.1(\mathrm{CH}), 132.5$ $(\mathrm{CH}), 126.2\left(\mathrm{C}^{\mathrm{IV}}\right), 124.0(\mathrm{CH}), 112.1\left(\mathrm{C}^{\mathrm{IV}}\right), 109.9\left(\mathrm{C}^{\mathrm{IV}}\right), 93.2$ $(\mathrm{C} \equiv \mathrm{C}), 85.2(\mathrm{C} \equiv \mathrm{C}), 72.2(\mathrm{Cp}(\mathrm{CH}) \mathrm{C} \equiv \mathrm{C}), 70.9(\mathrm{Cp}(\mathrm{CH})), 69.4$ $(\mathrm{Cp}(\mathrm{CH}) \mathrm{C} \equiv \mathrm{C}), 68.1\left(\mathrm{Cp}\left(\mathrm{C}^{\mathrm{IV}}\right) \mathrm{C} \equiv \mathrm{C}\right), 24.8\left(\mathrm{CH}_{3}\right), 13.6\left(\mathrm{CH}_{2} \mathrm{CH}_{3}\right)$, $-1.3\left(\mathrm{CH}_{2} \mathrm{CH}_{3}\right)$; Anal. Calc. $\left(\mathrm{ZnC}_{24} \mathrm{H}_{20} \mathrm{ClFeNO}\right): \mathrm{C}, 58.22 \% ; \mathrm{H}$, $4.07 \%$; N, 2.83\% Found: C, 58.33\%; H, 4.12\%; N, 2.91\%.

\section{Acknowledgements}

The research was supported by funding from the EPSRC (EP/ K035274/1, EP/K014070/1). CB acknowledges an EPSRC Doctoral Prize Fellowship for financial support. DWB acknowledges the Imperial-UBC Summer Research Placement Exchange 2014 for financial support. Purac Plc. are thanked for the donation of rac-lactide.

\section{References}

1 (a) P. J. Dijkstra, H. Z. Du and J. Feijen, Polym. Chem., 2011, 2, 520-527; (b) J.-C. Buffet and J. Okuda, Polym. Chem., 2011, 2, 2758-2763; (c) N. Ajellal, J. F. Carpentier, C. Guillaume, S. M. Guillaume, M. Helou, V. Poirier, 
Y. Sarazin and A. Trifonov, Dalton Trans., 2010, 39, 83638376; (d) R. H. Platel, L. M. Hodgson and C. K. Williams, Polym. Rev., 2008, 48, 11-63; (e) A. Arbaoui and C. Redshaw, Polym. Chem., 2010, 1, 801-826.

2 M. J. L. Tschan, E. Brule, P. Haquette and C. M. Thomas, Polym. Chem., 2012, 3, 836-851.

3 (a) A. Kowalski, A. Duda and S. Penczek, Macromolecules, 1998, 31, 2114; (b) H. Du, A. H. Velders, P. J. Dijkstra, J. Sun, Z. Zhong, X. Chen and J. Feijen, Chem. - Eur. J., 2009, 15, 9836-9845; (c) Z. Y. Zhong, P. J. Dijkstra and J. Feijen, Angew. Chem., Int. Ed., 2002, 41, 4510-4513; (d) M. Normand, V. Dorcet, E. Kirillov and J. F. Carpentier, Organometallics, 2013, 32, 1694-1709; (e) M. Bouyahyi, T. Roisnel and J.-F. Carpentier, Organometallics, 2011, 31, 1458-1466; $(f)$ M. Bouyahyi, T. Roisnel and J.-F. Carpentier, Organometallics, 2009, 29, 491-500; (g) M. Bouyahyi, E. Grunova, N. Marquet, E. Kirillov, C. M. Thomas, T. Roisnel and J. F. Carpentier, Organometallics, 2008, 27, 5815-5825; (h) T. M. Ovitt and G. W. Coates, J. Am. Chem. Soc., 2002, 124, 1316; (i) P. Hormnirun, E. L. Marshall, V. C. Gibson, A. J. P. White and D. J. Williams, J. Am. Chem. Soc., 2004, 126, 2688-2689; (j) D. J. Darensbourg and O. Karroonnirun, Organometallics, 2010, 29, 56275634.

4 (a) X. Y. Wang, K. R. Liao, D. P. Quan and Q. Wu, Macromolecules, 2005, 38, 4611-4617; (b) B. J. O'Keefe, L. E. Breyfogle, M. A. Hillmyer and W. B. Tolman, J. Am. Chem. Soc., 2002, 124, 4384-4393; (c) M. Stolt and A. Sodergard, Macromolecules, 1999, 32, 6412-6417; (d) A. B. Biernesser, B. Li and J. A. Byers, J. Am. Chem. Soc., 2013, 135, 16553-16560.

5 (a) M. H. Chisholm, J. C. Gallucci and K. Phomphrai, Inorg. Chem., 2004, 43, 6717-6725; (b) M. H. Chisholm, J. Gallucci and K. Phomphrai, Chem. Commun., 2003, 48-49; (c) M. Lamberti, A. Botta and M. Mazzeo, Appl. Organomet. Chem., 2014, 28, 140-145; (d) W. Yi and H. Ma, Inorg. Chem., 2013, 52, 11821-11835; (e) B. Liu, T. Roisnel, L. Maron, J.-F. Carpentier and Y. Sarazin, Chem. - Eur. J., 2013, 19, 3986-3994; (f) M.-W. Hsiao and C.-C. Lin, Dalton Trans., 2013, 42, 2041-2051; $(g)$ L. Clark, G. B. Deacon, C. M. Forsyth, P. C. Junk, P. Mountford, J. P. Townley and J. Wang, Dalton Trans., 2013, 42, 9294-9312; $(h)$ B. Liu, T. Roisnel, J.-P. Guegan, J.-F. Carpentier and Y. Sarazin, Chem. - Eur. J., 2012, 18, 6289-6301; (i) J. P. Davin, J.-C. Buffet, T. P. Spaniol and J. Okuda, Dalton Trans., 2012, 41, 12612-12618; $(j)$ M. G. Cushion and P. Mountford, Chem. Commun., 2011, 47, 2276-2278; (k) J.-C. Buffet, J. P. Davin, T. P. Spaniol and J. Okuda, New J. Chem., 2011, 35, 2253-2257; (l) Z. Y. Zhong, M. J. K. Ankone, P. J. Dijkstra, C. Birg, M. Westerhausen and J. Feijen, Polym. Bull., 2001, 46, 51-57.

6 (a) M. J. Walton, S. J. Lancaster and C. Redshaw, ChemCatChem, 2014, 6, 1892-1898; (b) H. Wang, Y. Yang and H. Ma, Macromolecules, 2014, 47, 7750-7764; (c) F. Drouin, T. J. J. Whitehorne and F. Schaper, Dalton Trans., 2011, 40, 1396-1400; (d) M. H. Chisholm, J. C. Gallucci and
K. Phomphrai, Inorg. Chem., 2005, 44, 8004-8010; (e) B. M. Chamberlain, M. Cheng, D. R. Moore, T. M. Ovitt, E. B. Lobkovsky and G. W. Coates, J. Am. Chem. Soc., 2001, 123, 3229-3238; $(f)$ M. H. Chisholm, J. Gallucci and K. Phomphrai, Inorg. Chem., 2002, 41, 2785-2794; (g) V. Poirier, T. Roisnel, J.-F. Carpentier and Y. Sarazin, Dalton Trans., 2009, 9820-9827; (h) J. C. Wu, B. H. Huang, M. L. Hsueh, S. L. Lai and C. C. Lin, Polymer, 2005, 46, 9784-9792; (i) W.-C. Hung and C.-C. Lin, Inorg. Chem., 2009, 48, 728-734; (j) L. Wang and H. Ma, Macromolecules, 2010, 43, 6535-6537; ( $k$ ) T. J. J. Whitehorne, B. Vabre and F. Schaper, Dalton Trans., 2014, 43, 6339-6352; (l) C. Gallegos, V. Tabernero, F. M. Garcia-Valle, M. E. G. Mosquera, T. Cuenca and J. Cano, Organometallics, 2013, 32, 6624-6627.

7 (a) J. Zhang, J. Xiong, Y. Sun, N. Tang and J. Wu, Macromolecules, 2014, 47, 7789-7796; (b) L. N. Saunders, L. N. Dawe and C. M. Kozak, J. Organomet. Chem., 2014, 749, 34-40; (c) B. Calvo, M. G. Davidson and D. Garcia-Vivo, Inorg. Chem., 2011, 50, 3589-3595; (d) Y. Huang, Y.-H. Tsai, W.-C. Hung, C.-S. Lin, W. Wang, J.-H. Huang, S. Dutta and C.-C. Lin, Inorg. Chem., 2010, 49, 9416-9425.

8 (a) Y. Huang, W. Wang, C.-C. Lin, M. P. Blake, L. Clark, A. D. Schwarz and P. Mountford, Dalton Trans., 2013, 42, 9313-9324; (b) Y. Lemmouchi, M. C. Perry, A. J. Amass, K. Chakraborty and E. Schacht, J. Polym. Sci., Part A: Polym. Chem., 2008, 46, 5348-5362; (c) L. Sipos and M. Zsuga, J. Macromol. Sci., Part A: Pure Appl. Chem., 1997, 34, 12691284; (d) Z. Jedlinski, P. Kurcok and R. W. Lenz, J. Macromol. Sci., Part A: Pure Appl. Chem., 1995, 32, 797-810; (e) Z. Jedlinski, P. Kurcok, M. Kowalczuk, A. Matuszowicz, P. Dubois, R. Jerome and H. R. Kricheldorf, Macromolecules, 1995, 28, 7276-7280; (f) H. R. Kricheldorf and C. Boettcher, Makromol. Chem., 1993, 73, 47-64.

9 (a) Y. Sarazin, R. H. Howard, D. L. Hughes, S. M. Humphrey and M. Bochmann, Dalton Trans., 2006, 340-350; (b) Z. R. Turner, J.-C. Buffet and D. O'Hare, Organometallics, 2014, 33, 3891-3903; (c) C. J. Chuck, M. G. Davidson, G. G. du Sart, P. K. Ivanova-Mitseva, G. I. Kociok-Koehn and L. B. Manton, Inorg. Chem., 2013, 52, 10804-10811; (d) A. Sauer, A. Kapelski, C. Fliedel, S. Dagorne, M. Kol and J. Okuda, Dalton Trans., 2013, 42, 9007-9023; (e) B. J. Jeffery, E. L. Whitelaw, D. Garcia-Vivo, J. A. Stewart, M. F. Mahon, M. G. Davidson and M. D. Jones, Chem. Commun., 2011, 47, 12328-12330; (f) J.-C. Buffet, A. N. Martin, M. Kol and J. Okuda, Polym. Chem., 2011, 2, 2378-2384; (g) C. K. A. Gregson, V. C. Gibson, N. J. Long, E. L. Marshall, P. J. Oxford and A. J. P. White, J. Am. Chem. Soc., 2006, 128, 7410-7411; (h) C. K. A. Gregson, I. J. Blackmore, V. C. Gibson, N. J. Long, E. L. Marshall and A. J. P. White, Dalton Trans., 2006, 3134-3140; (i) S. Gendler, S. Segal, I. Goldberg, Z. Goldschmidt and M. Kol, Inorg. Chem., 2006, 45, 47834790; (j) A. J. Chmura, M. G. Davidson, M. D. Jones, M. D. Lunn, M. F. Mahon, A. F. Johnson, P. Khunkamchoo, S. L. Roberts and S. S. F. Wong, Macromolecules, 2006, 39, 
7250-7257; (k) Y. Kim, G. K. Jnaneshwara and J. G. Verkade, Inorg. Chem., 2003, 42, 1437-1447.

10 (a) C. Bakewell, A. J. P. White, N. J. Long and C. K. Williams, Inorg. Chem., 2013, 52, 12561-12567; (b) C. Bakewell, R. H. Platel, S. K. Cary, S. M. Hubbard, J. M. Roaf, A. C. Levine, A. J. P. White, N. J. Long, M. Haaf and C. K. Williams, Organometallics, 2012, 31, 4729-4736; (c) K. Sokołowski, I. Justyniak, W. Śliwiński, K. Sołtys, A. Tulewicz, A. Kornowicz, R. Moszyński, J. Lipkowski and J. Lewiński, Chem. - Eur. J., 2012, 18, 5637-5645; (d) W. Zhang, S. Liu, W. Yang, X. Hao, R. Glaser and W. H. Sun, Organometallics, 2012, 31, 8178-8188; (e) B. Kamenar, C. K. Prout and J. D. Wright, J. Chem. Soc., 1965, 4851-4867; (f) M. Pasquali, P. Fiaschi, C. Floriani and P. F. Zanazzi, J. Chem. Soc., Chem. Commun., 1983, 613-614; (g) W.-H. Sun, M. Shen, W. Zhang, W. Huang, S. Liu and C. Redshaw, Dalton Trans., 2011, 40, 26452653.

11 G. Delapierre, J. M. Brunel, T. Constantieux and G. Buono, Tetrahedron: Asymmetry, 2001, 12, 1345-1352.

12 (a) Y. Fazaeli, M. M. Amini and S. W. Ng, Acta Crystallogr., Sect. E: Struct. Rep. Online, 2008, 64, m1509-m1509; (b) M. Mirzaee and M. M. Amini, Appl. Organomet. Chem., 2005, 19, 339-342; (c) Y. Fazaeli, E. Najafi, M. M. Amini and S. W. Ng, Acta Crystallogr., Sect. E: Struct. Rep. Online, 2009, 65, m271-m271; (d) P. H. Bird, A. R. Fraser and C. F. Lau, Inorg. Chem., 1973, 12, 1322-1328; (e) W. F. Zeng, Y. S. Chen, M. Y. Chiang, S. S. Chern and C. P. Cheng, Polyhedron, 2002, 21, 1081-1087; $(f)$ F. Grasset, J.-B. Cazaux, L. Magna, P. Braunstein and H. Oliver-Bourbigou, Dalton Trans., 2012, 41, 10396-10404.

13 K. Sokołowski, I. Justyniak, W. Śliwiński, K. Sołtys, A. Tulewicz, A. Kornowicz, R. Moszyński, J. Lipkowski and J. Lewiński, Chem. - Eur. J., 2012, 18, 5637-5645.

14 K. L. Orchard, J. E. Harris, A. J. P. White, M. S. P. Shaffer and C. K. Williams, Organometallics, 2011, 30, 2223-2229.

15 (a) X. Wang, A. Thevenon, J. L. Brosmer, I. Yu, S. I. Khan, P. Mehrkhodavandi and P. L. Diaconescu, J. Am. Chem. Soc., 2014, 136, 11264-11267; (b) E. M. Broderick, P. S. Thuy-Boun, N. Guo, C. S. Vogel, J. Sutter, J. T. Miller, K. Meyer and P. L. Diaconescu, Inorg. Chem., 2011, 50, 2870-2877; (c) E. M. Broderick, N. Guo, C. S. Vogel, C. L. Xu, J. Sutter, J. T. Miller, K. Meyer,
P. Mehrkhodavandi and P. L. Diaconescu, J. Am. Chem. Soc., 2011, 133, 9278-9281.

16 J. Coudane, C. Ustariz-Peyret, G. Schwach and M. Vert, J. Polym. Sci., Part A: Polym. Chem., 1997, 35, 1651-1658.

17 (a) E. L. Whitelaw, M. D. Jones and M. F. Mahon, Inorg. Chem., 2010, 49, 7176-7181; (b) K.-C. Hsieh, W.-Y. Lee, L.-F. Hsueh, H. M. Lee and J.-H. Huang, Eur. J. Inorg. Chem., 2006, 2006, 2306-2312; (c) M. Hu, M. Wang, H. Zhu, L. Zhang, H. Zhang and L. Sun, Dalton Trans., 2010, 39, 4440-4446.

18 (a) S. K. Russell, C. L. Gamble, K. J. Gibbins, K. C. S. Juhl, W. S. Mitchell, A. J. Tumas and G. E. Hofmeister, Macromolecules, 2005, 38, 10336-10340; (b) A. J. Chmura, M. G. Davidson, C. J. Frankis, M. D. Jones and M. D. Lunn, Chem. Commun., 2008, 1293-1295; (c) A. Stopper, J. Okuda and M. Kol, Macromolecules, 2012, 45, 698-704; (d) J.-C. Buffet and J. Okuda, Chem. Commun., 2011, 47, 4796-4798.

19 J. A. Dean, Lange's Handbook of Chemistry, McGraw-Hill Inc., 1999.

20 (a) M. H. Chisholm, J. C. Gallucci, H. Zhen and J. C. Huffman, Inorg. Chem., 2001, 40, 5051-5054; (b) M. P. Coles and P. B. Hitchcock, Eur. J. Inorg. Chem., 2004, 2004, 2662-2672.

21 C. C. Roberts, B. R. Barnett, D. B. Green and J. M. Fritsch, Organometallics, 2012, 31, 4133-4141.

22 (a) H. Y. Chen, H. Y. Tang and C. C. Lin, Macromolecules, 2006, 39, 3745-3752; (b) C. K. Williams, L. E. Breyfogle, S. K. Choi, W. Nam, V. G. Young, M. A. Hillmyer and W. B. Tolman, J. Am. Chem. Soc., 2003, 125, 1135011359.

23 (a) R. H. Platel, A. J. P. White and C. K. Williams, Chem. Commun., 2009, 4115-4117; (b) N. Ajellal, J. F. Carpentier, C. Guillaume, S. M. Guillaume, M. Helou, V. Poirier, Y. Sarazin and A. Trifonov, Dalton Trans., 2010, 39, 83638376; (c) M. Bouyahyi, N. Ajellal, E. Kirillov, C. M. Thomas and J. F. Carpentier, Chem. - Eur. J., 2011, 17, 1872-1883; (d) K. Nie, L. Fang, Y. Yao, Y. Zhang, Q. Shen and Y. Wang, Inorg. Chem., 2012, 51, 11133-11143; (e) H. Ma, T. P. Spaniol and J. Okuda, Angew. Chem., Int. Ed., 2006, 45, 7818-7821.

24 M. H. Chisholm, K. Choojun, A. S. Chow and G. Fraenkel, Angew. Chem., Int. Ed., 2013, 52, 3264-3266. 